A Literature Review of Processes for Gravel Deposit Identification in the Lower Mississippi River

David S. Biedenharn and Maureen K. Corcoran

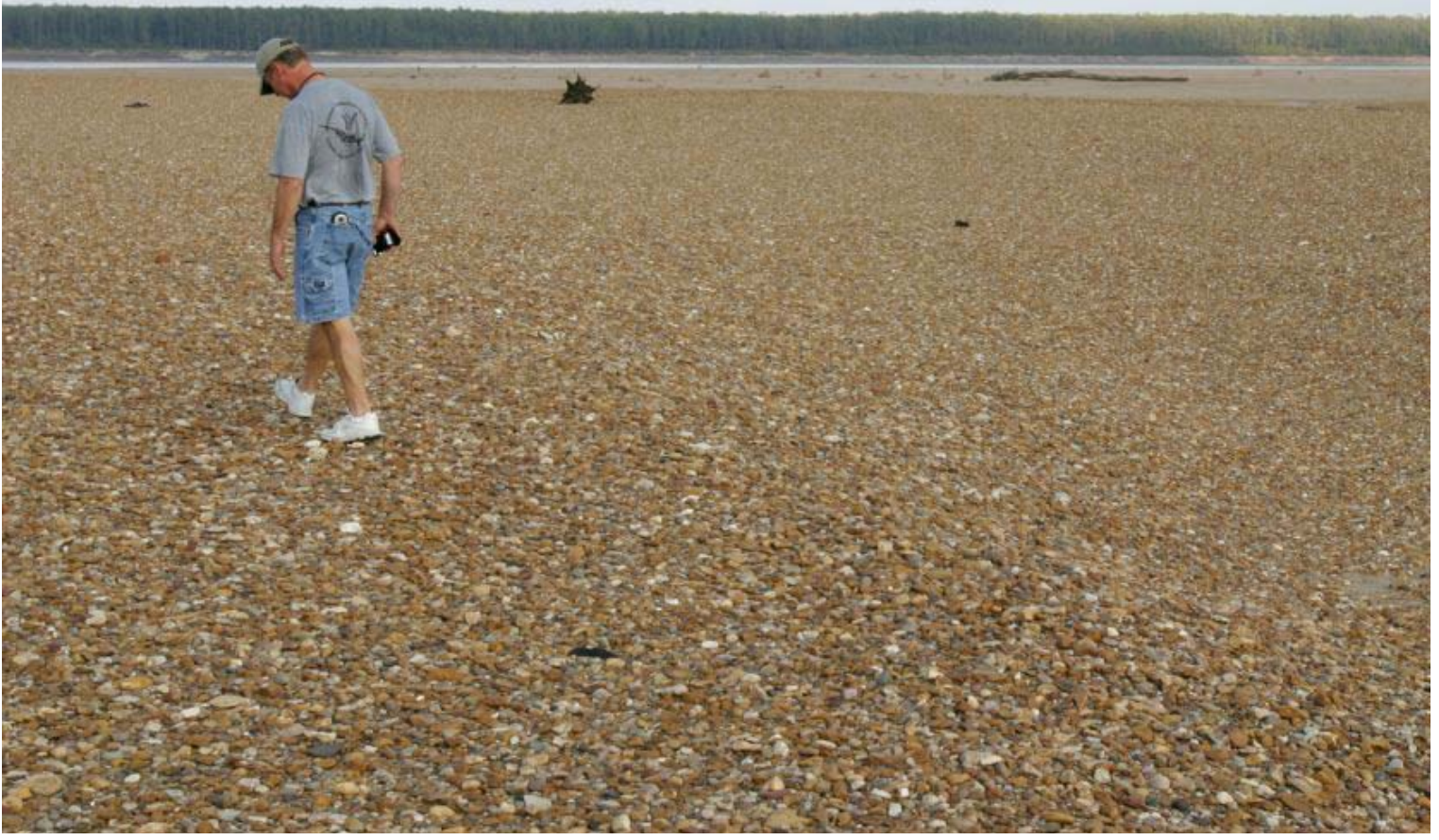


July 2010

\section{A Literature Review of Processes for Gravel Deposit Identification in the Lower Mississippi River}

David S. Biedenharn

Biedenharn Group, LLC

3303 Woodlands Place

Vicksburg, MS 39180-5759

Maureen K. Corcoran

Geotechnical and Structures Laboratory

U.S. Army Engineer Research and Development Center

3909 Halls Ferry Road

Vicksburg, MS 39180-6199

Approved for public release; distribution is unlimited.

Prepared for U.S. Army Engineer Division, Mississippi Valley Vicksburg, MS 39181-0080 


\begin{abstract}
The purpose of this study was to identify feasible techniques for the detection and identification of gravel deposits in the Lower Mississippi River (LMR). This study involved a thorough review of literature concerning investigative techniques used to classify sediment types in bodies of water, as well as interviews with experts in this field. Researchers identified the technique or combination of techniques that have the greatest potential for use on the LMR and recommended a plan for testing those techniques there. This study revealed that direct observation and acoustic techniques can be used to classify the subaqueous bed material in the LMR. Direct observation is obviously the most reliable method, but it is limited to exposed areas of gravel. It is recommended that a detailed visual inspection of the river from Cairo to Old River be conducted with focus on the identification of exposed gravel bars. With respect to acoustical methods, GeoSwath Plus appears to have the greatest potential to map large areas of the river. Both the visual inspections and the GeoSwath Plus system will provide information only about the surface bed material. To assess the potential volume of gravel available in the system, an estimate of the depth of these deposits is needed. Therefore, it is recommended that a subbottom profiling system be applied to the selected test sites to determine its ability to both classify buried gravel strata and determine the vertical extent of these strata. The two-dimensional model being developed by the U.S. Army Engineer Research and Development Center should be applied on the gravel test sites.
\end{abstract}

DISCLAIMER: The contents of this report are not to be used for advertising, publication, or promotional purposes. Citation of trade names does not constitute an official endorsement or approval of the use of such commercial products. All product names and trademarks cited are the property of their respective owners. The findings of this report are not to be construed as an official Department of the Army position unless so designated by other authorized documents. 


\section{Contents}

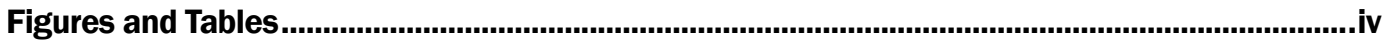

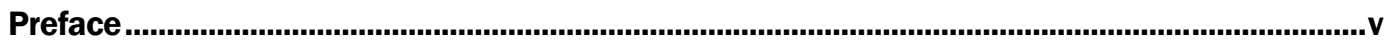

Unit Conversion Factors.......................................................................................................................vi

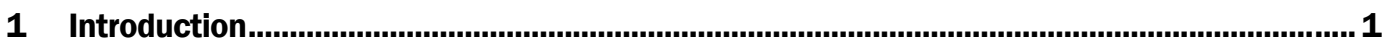

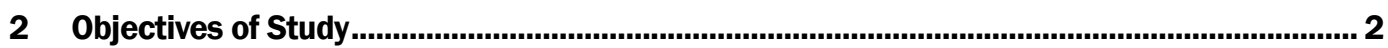

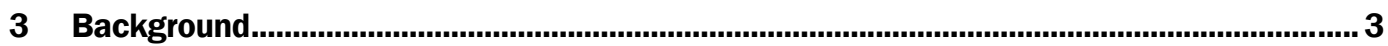

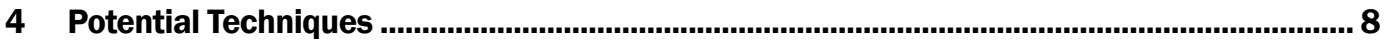

Subaqueous bed materials........................................................................................ 8

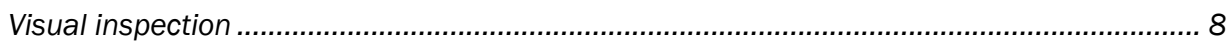

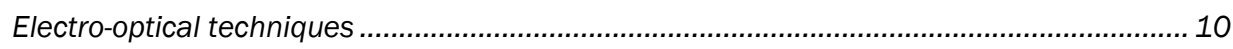

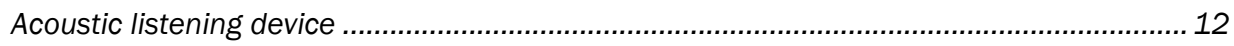

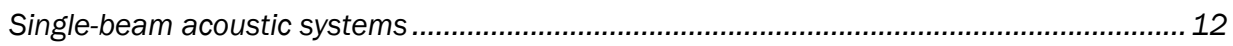

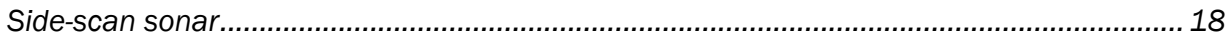

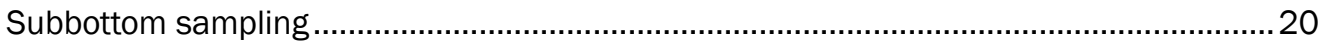

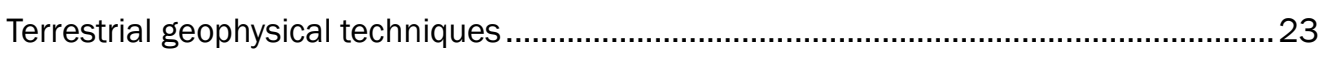

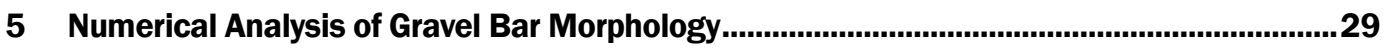

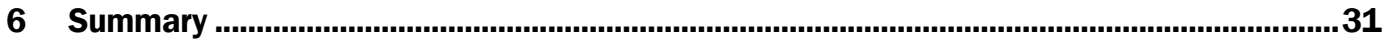

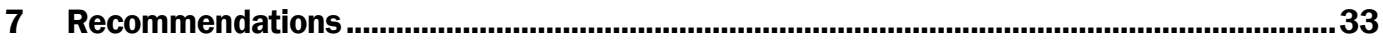

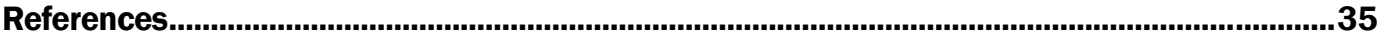

Report Documentation Page 


\section{Figures and Tables}

\section{Figures}

Figure 1. Lower Mississippi River vicinity map.

Figure 2. Composition of 1932 bed material (averaged by 25 miles) using the extended Wentworth scale, a grade scale for classifying the diameter of sediment (Nordin and Queen 1992).

Figure 3. Composition of 1989 bed material, averaged by 25 miles (Nordin and Queen 1992).

Figure 4. Difference in percentage of gravel between 1989 and 1932 samples averaged by 25 miles (Nordin and Queen 1992).

Figure 5. Typical gravel bar near Mhoon Landing, MS (approximate RM 685)................................. 9

Figure 6. Gravel locations from topographic mapping and field observations in the Mhoon Landing area.

Figure 7. Benthic cover classification mapped by CASI (from Anstee et al. 1997). ......................... 12

Figure 8. The SHOALS system (from Lillycrop et al. 1996)................................................................ 13

Figure 9. SHOALS application of Lake Tahoe area (U.S. Geological Survey 2000). ......................... 14

Figure 10. Example showing mapped substrate types in the Lower Bad River

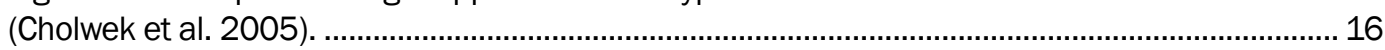

Figure 11. QTC-View window displays (Kvitek et al. 1999)............................................................... 17

Figure 12. Side-scan image of seabed with rock scarps (from Tamsett 2001, with permission: Kongsberg GeoAcoustics).

Figure 13. Classified image showing rock scarps (from Tamsett 2001, with permission: Kongsberg GeoAcoustics). 19

Figure 14. Elements of the acoustic subbottom profiling equipment (Murphy 1983)..................... 21

Figure 15. Subbottom profile between RM 526.3 and RM 530.4 (Murphy 1983)......................... 22

Figure 16. Seismic reflection data showing layers within the alluvium and the top of the bedrock (Lucius et al. 2007).

Figure 17. Interpretations of resistivity models for multi-electrode data collected over a sand and gravel deposit (Lucius et al. 2007).

Figure 18. Interpretation of GPR data collected near an active sand and gravel quarry (Lucius et al. 2007).

Figure 19. Bedrock depth in meters determined by use of TDEM soundings on an alluvial floodplain (Lucius et al. 2007).

Figure 20. Contour map of ground conductivity generated by FDEM (from Green 2007, with permission). Fine-grained sediments, such as clay and silt, are electrically conductive and are shown as blue, green, and yellow. Porous grained sediments, such as sands and gravels, are electrically resistive and are shown as orange, red, and pink.

Figure 21. Bed topography changes in a dike-controlled channel. Bed scour is depicted by the blue colors while fill is depicted by red colors. The darker the color, the more severe the scour or fill. The lighter colors (light greens, pink, and beige) reflect areas with little change.

\section{Tables}

Table 1. Comparison of potential gravel detection techniques 


\section{Preface}

This investigation of potential techniques that can be used to identify gravel deposits in the Lower Mississippi River was conducted at the request of the U.S. Army Engineer Division, Mississippi Valley (MVD), Vicksburg, MS. David Vigh was the technical point of contact at MVD.

This investigation was conducted during the period September 2007 to April 2008 by the Geotechnical and Structures Laboratory (GSL) of the U.S. Army Engineer Research and Development Center (ERDC). Principal investigators for the study were Dr. Maureen K. Corcoran, GSL, and Dr. David Biedenharn of Biedenharn Group, LLC.

The research was accomplished under the supervision of Bartley P. Durst, Chief, Geosciences and Structures Division; Dr. Michael K. Sharp, GSL Technical Directors' Office; Dr. William P. Grogan, Deputy Director, GSL; and Dr. David W. Pittman, Director, GSL.

COL Gary E. J ohnston was Commander and Executive Director of ERDC. Dr. J effery P. Holland was Director. 


\section{Unit Conversion Factors}

\begin{tabular}{|l|c|l|}
\hline Multiply & By & To Obtain \\
\hline feet & 0.3048 & meters \\
\hline miles (U.S. statute) & $1,609.347$ & meters \\
\hline
\end{tabular}




\section{Introduction}

The U.S. Fish and Wildlife Service's (USFWS 1990) listing of the pallid sturgeon (Scaphirhynchus albus) as a federally endangered species added support for recovery efforts aimed at increasing the pallid sturgeon population in the Lower Mississippi River. A critical factor in recovery of the pallid sturgeon is the availability and quality of spawning habitat within the river system. Although little is known about the pallid sturgeon's spawning needs, scientists believe it prefers a coarse gravel, boulder, or bedrock environment (Laustrup et al. 2007). Locating these gravel deposits and understanding the morphological processes associated with these deposits are critical to the implementation of successful recovery alternatives. Unfortunately, there is limited information with respect to gravel features on the Lower Mississippi River.

The U.S. Army Engineer Division, Mississippi Valley (MVD), recognized the benefits of identifying gravel deposits and requested that the U.S. Army Engineer Research and Development Center (ERDC) investigate existing techniques used to identify gravel deposits. At the request of MVD, ERDC researchers also developed a methodology to locate gravel deposits and map the dynamic nature of these deposits. This report is a compilation of the investigation. 


\section{Objectives of Study}

The assessment of gravel locations along the Lower Mississippi River can be accomplished in three related phases: Phase I, literature review and recommendations; Phase II, proof-of-concept of proposed field methods (based on Phase I); and Phase III, numerical model analysis. This report provides the results of the Phase I literature review.

The primary objectives of the Phase I study were as follows:

- Conduct a thorough literature review of investigative techniques used to classify sediment types in bodies of water.

- Identify the technique or combination of techniques that has the greatest potential for use on the Lower Mississippi River.

- Recommend a plan for testing these techniques on the Lower Mississippi River. 


\section{Background}

The Lower Mississippi River flows from the confluence of the Ohio River at Cairo, IL, to the Gulf of Mexico at Head of Passes, LA (Figure 1). Historically, the river meandered freely through most of its alluvial valley, continuously changing position, shape, and other morphological characteristics in response to variations in discharge, sediment loads, boundary conditions, and bed materials (stratigraphy of substratum). One consequence of active channel migration was that the river was continually exposing new gravel sources in terraces within the floodplain. However, during the 1930s and 1940s, the morphology of the Lower Mississippi River was altered by various engineering modifications for flood control and navigation improvements. The construction of revetments along the streambanks has restricted further meandering. Although the river can no longer adjust laterally through meander migration, it is still a very dynamic river with adjustments being restricted to changes in crosssectional shape and longitudinal bed profile. These local adjustments occur in response to changes in flows, sediment supply, channel alignment, and other factors and result in gravel deposits being exposed during one period and buried by sands during another.

The essentially fixed alignment of the present-day river means that the river no longer migrates through the valley, exposing new gravel sources. Therefore, sources of new gravel are restricted to those in the bed, in bars, and in islands (Lagasse et al. 1980). In addition, tributaries of the Mississippi River may also provide new sources of gravel.

Analyses of bed material gradations along the thalweg of the Mississippi River between Cairo, IL, and Head of Passes, LA (Figure 1), in 1932 and 1989 revealed the presence of gravel throughout much of the channel (Nordin and Queen 1992). As expected, the percent of gravel in the bed decreased in the downstream direction. Figures 2 and 3 show the composition of the bed material along the river in 1932 and 1989, respectively. Figure 4 shows the difference in percentage of gravel between 1989 and 1932 averaged by 25-mile reaches. As shown in Figure 3, there was significantly less gravel in the channel in 1989 compared with 1932. 


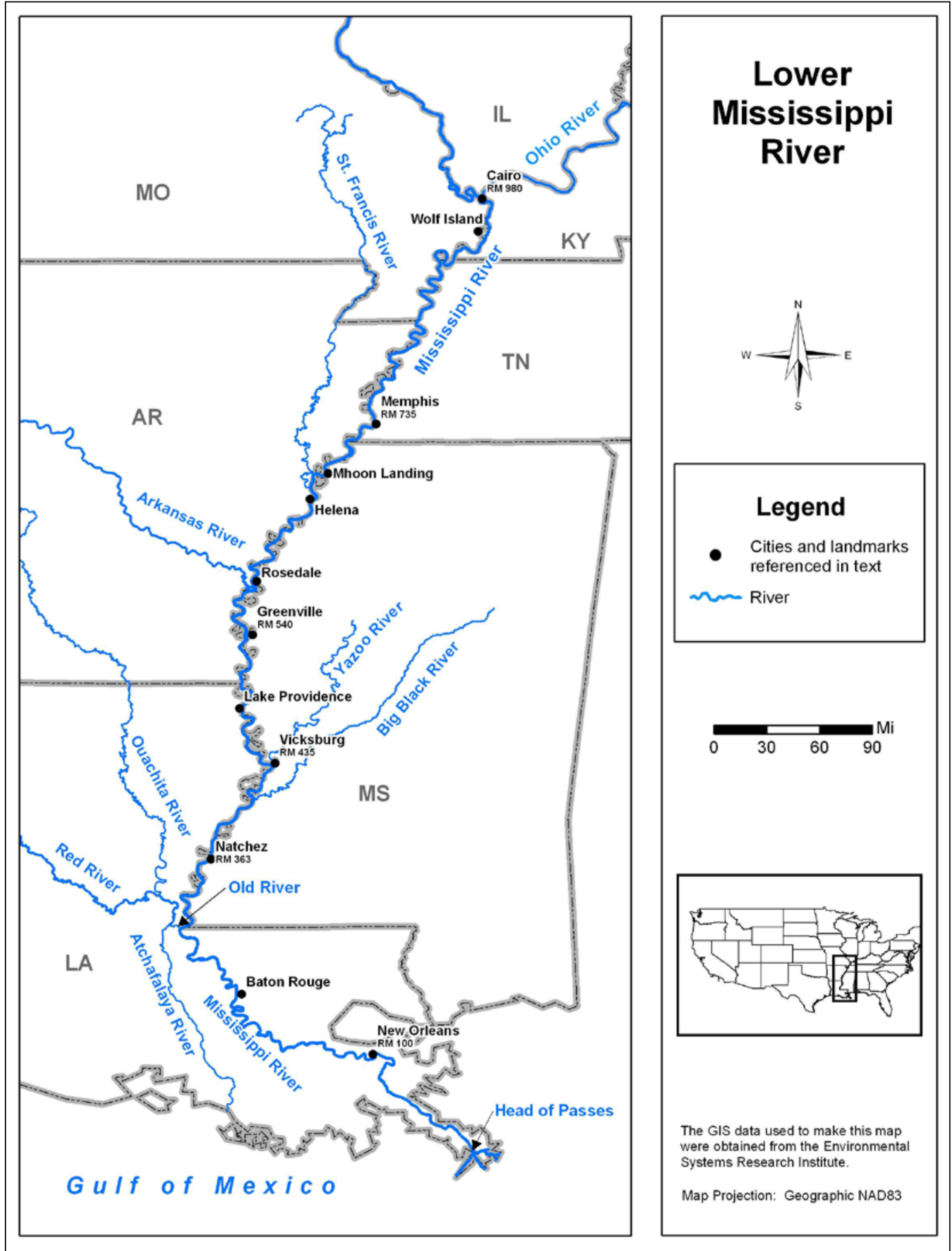

Figure 1. Lower Mississippi River vicinity map. 


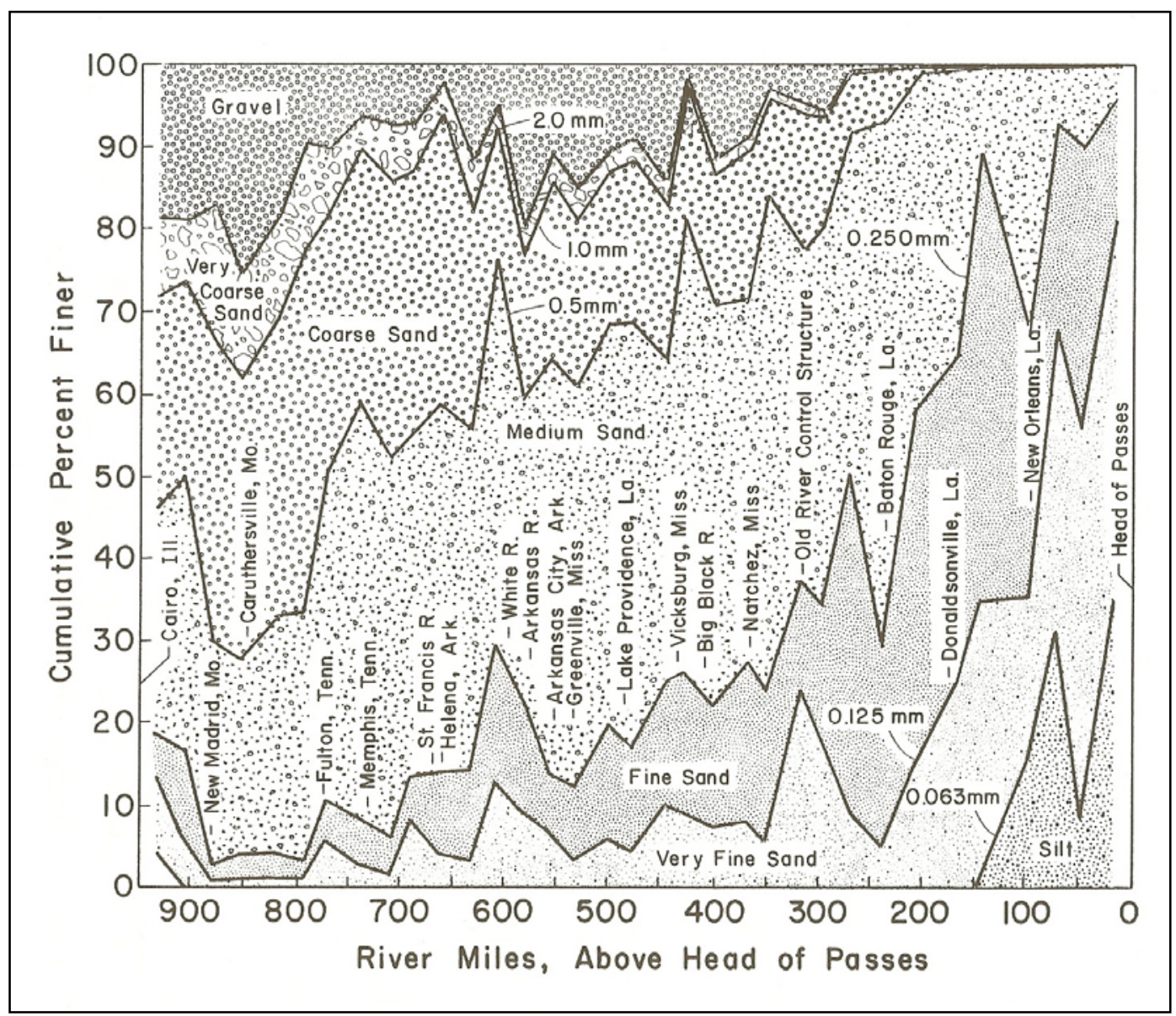

Figure 2. Composition of 1932 bed material (averaged by 25 miles) using the extended Wentworth scale, a grade scale for classifying the diameter of sediment (Nordin and Queen 1992).

Downstream of the vicinity of the Old River Control Structure (River Mile (RM) 315), there was very little gravel in the bed in either of the surveys. Nordin and Queen (1992) noted the presence of numerous exposed gravel bars during their 1989 survey of the river, although Figure 4 shows a decrease in the percentage of gravel in the bed material. They also reported that probing at Wolf Island, about 45 miles south of Cairo, IL, indicated the presence of gravel extending into the channel bed beneath a thin veneer $(<1 \mathrm{ft})$ of sand. Sand covering gravel is not uncommon along the river, which makes it difficult to use observation to determine the amount of available gravel in the river. 


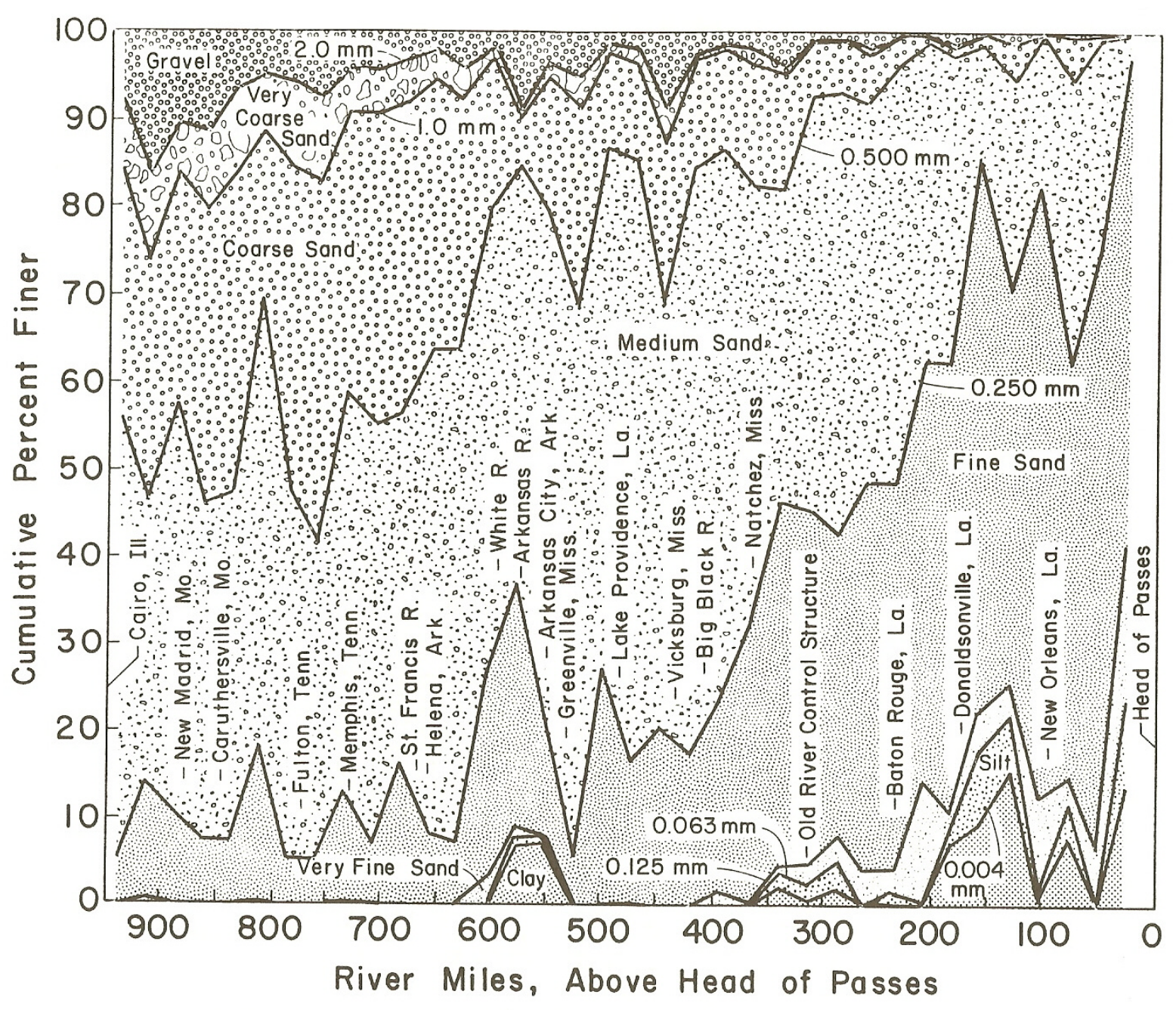

Figure 3. Composition of 1989 bed material, averaged by 25 miles (Nordin and Queen 1992). 


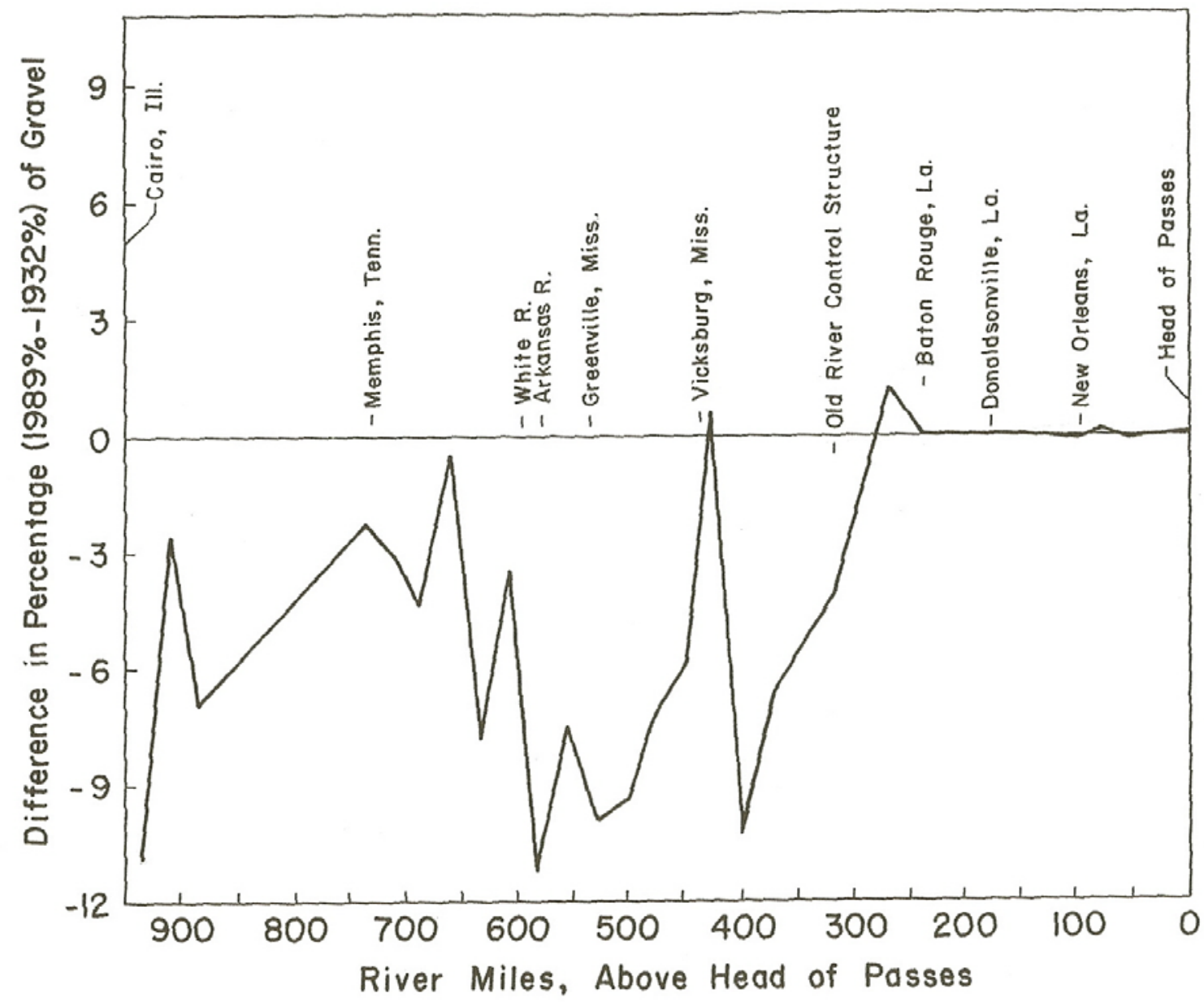

Figure 4. Difference in percentage of gravel between 1989 and 1932 samples averaged by 25 miles (Nordin and Queen 1992). 


\section{Potential Techniques}

Different techniques for detecting gravel sources in the river were investigated for this report and are discussed in the following sections. The first section addresses methods used to identify gravel deposits on the channel bottom, referred to herein as the subaqueous bed material. The second section deals with techniques that have the potential to identify subbottom material beneath the subaqueous bed material. The third section addresses surface geophysical techniques that may have the capability to detect buried gravel deposits.

\section{Subaqueous bed materials}

The most reliable methods of classifying the composition of subaqueous bed material in a river are direct observation by divers, collection of grab samples, and cores. Although these techniques are generally impractical to deploy on a river with the spatial extent and flow velocity of the Mississippi River, they may be used selectively to develop ground-truth data for calibrating models.

This section discusses only techniques used to detect gravel on the channel bed that is not buried by other sediment in subaqueous conditions.

\section{Visual inspection}

One of the simplest and least costly methods for identifying terrestrial or exposed gravel deposits is to conduct a visual inspection of the river. Visual inspection can be accomplished by boat or helicopter and should be conducted at low-water conditions. Conditions during fall 2007 were ideal because of the extremely low water levels in the river. Figure 5 shows a typical gravel bar near Mhoon Landing (approximate RM 685) that was exposed during low-water conditions in fall 2007.

During such a reconnaissance, the location and extent of each observed gravel deposit should be mapped with a global positioning system (GPS). While visual inspection provides a good first approximation of the number and size of exposed gravel areas in the river, it does have limitations, including the following: 


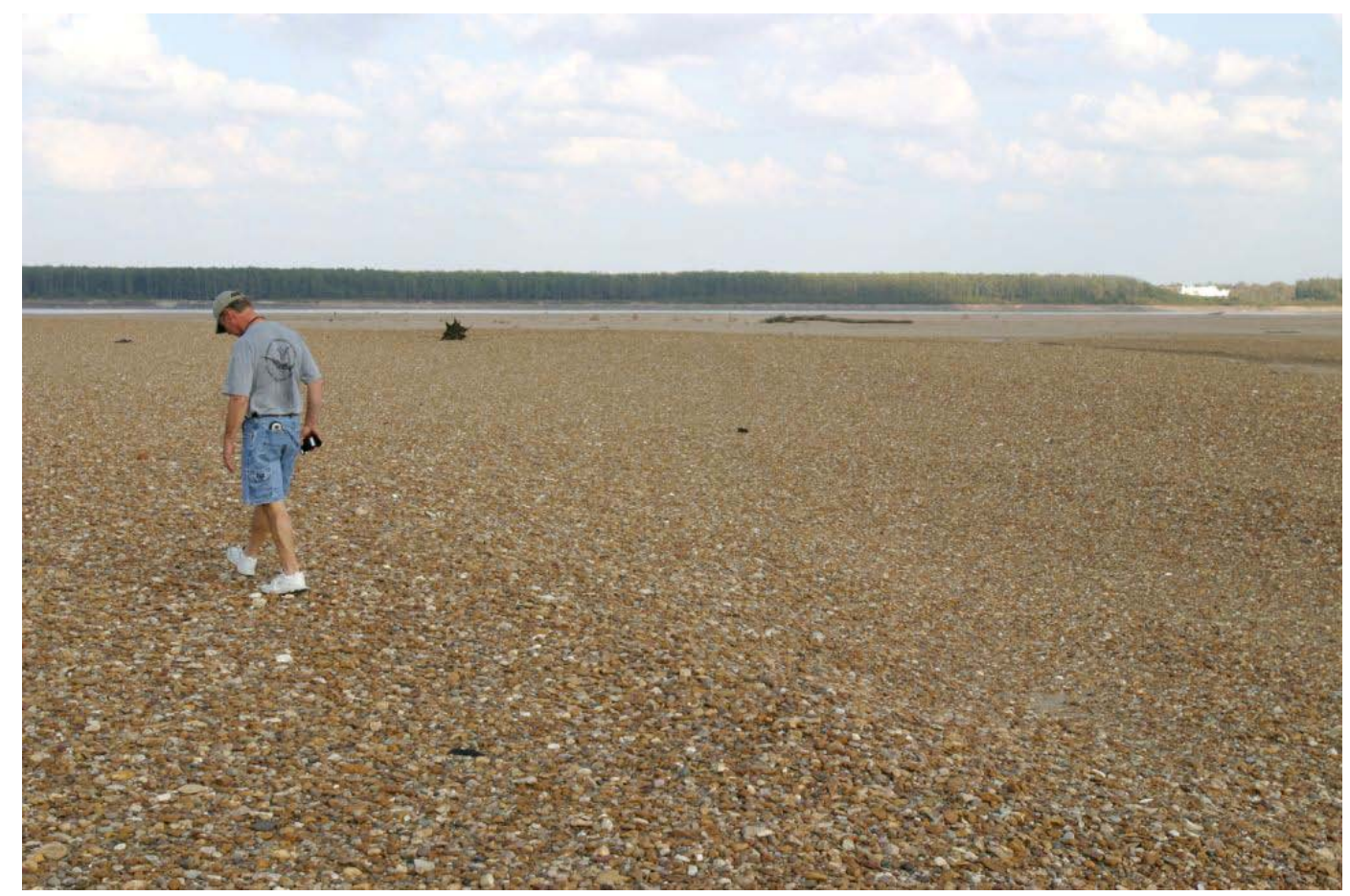

Figure 5. Typical gravel bar near Mhoon Landing, MS (approximate RM 685).

- Only gravel bars exposed at the time of the survey can be mapped. Gravel deposits covered by even a thin veneer of sand will not be observed. Therefore, probing of the bars is recommended, but this can significantly increase the time and complexity of the survey.

- Because the depth and thickness of the deposit will be unknown, only the lateral extent of the exposed gravel deposit can be mapped.

The ability to determine the depth of the gravel deposits is a limitation of all of the techniques described in this section. One way to address or mitigate this limitation is to use data from the numerous levee and other borings located along both sides of the river. The thickness of the gravel deposits recorded in the borings adjacent to observed gravel deposits in the river can be used to estimate the thickness and area of the observed deposit through extrapolation in geologic cross sections. While this method may not provide a direct measurement of the depth of the deposit, it will provide a reasonable approximation.

Red Hen Systems, Inc., a developer of multimedia video and maps, conducted a survey on the river from Cairo, IL, to Head of Passes, LA, in November 2007. While this survey was not directly tasked with mapping gravel locations, most of the gravel bars were well exposed during the 
helicopter flight. However, the composition of the bars could not be identified from watching the Red Hen videos. While the Red Hen videos are extremely useful for identifying many of the morphologic features and structures in the river, determining with certainty the composition of the bars was difficult. However, a Red Hen flight that focused only on the bars may be a good tool for identifying the composition of the bars because of increased resolution at a larger scale.

Aerial photographs and topographic maps coupled with a geographic information system for change analysis can also be helpful in locating and displaying gravel locations along the river. Topographic maps sometime delineate the type of bed material found on bars and islands in the river. Figure 6 shows an aerial photograph superimposed on a topographic map of the Mhoon Landing area just upstream of Helena, AR.

\section{Electro-optical techniques}

A number of relatively new techniques that use electro-optical spectra to map surfaces (Kvitek et al. 1999) have emerged in recent years. The Compact Airborne Spectrographic Imager (CASI) and light detection and ranging (LIDAR) technology are deployed from either a fixed-wing aircraft or a helicopter (Kvitek et al. 1999). Another electro-optical technique, the laser-sine scanner (LLS), is waterborne. Electro-optical techniques have been used quite successfully in coastal marine and inland terrestrial mapping. However, their utility in riverine mapping on a system such as the Lower Mississippi River is limited due to the lack of water clarity.

CASI has been used successfully to map vegetation and substrate types in terrestrial freshwater and marine environments (Kvitek et al. 1999). In one example (Figure 7), CASI was used to map benthic algae and substrate type in shallow coastal waters (Anstee et al. 1997).

LIDAR has been used to map topography and bathymetry and to detect objects in both marine and freshwater environments. The Scanning Hydrographic Operational Airborne LIDAR Survey (SHOALS) system shown as Figure 8 is capable of mapping coastal topography and bathymetry simultaneously (Lillycrop et al. 1996). Figure 9 shows a U.S. Army Corps of Engineers SHOALS survey of the Lake Tahoe area. The shaded relief image (Figure 9) was developed by combining LIDAR and multibeam bathymetry over Landsat-7 imagery for the surrounding land (U.S. Geological Survey 2000). 


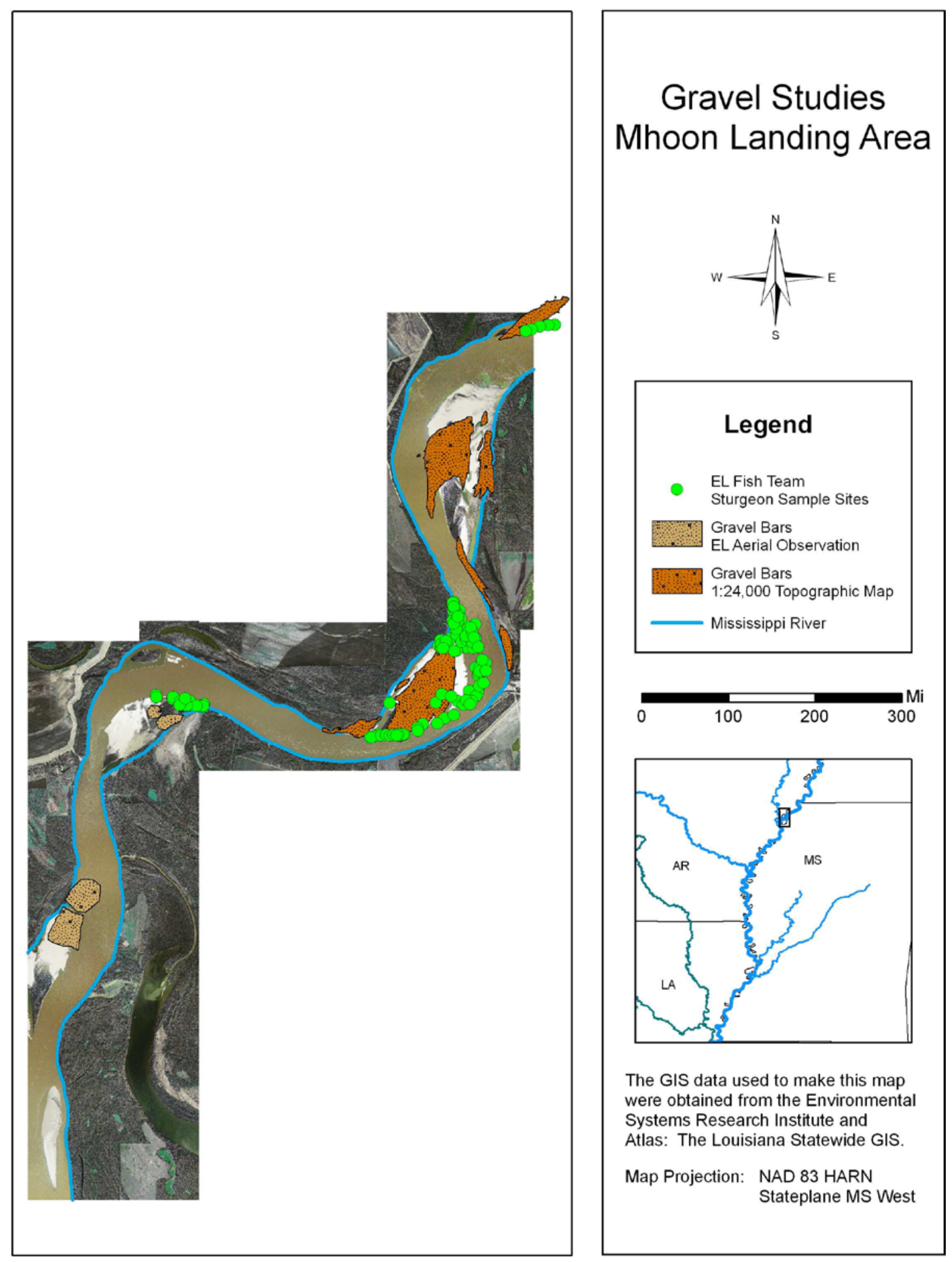

Figure 6. Gravel locations from topographic mapping and field observations in the Mhoon Landing area. 


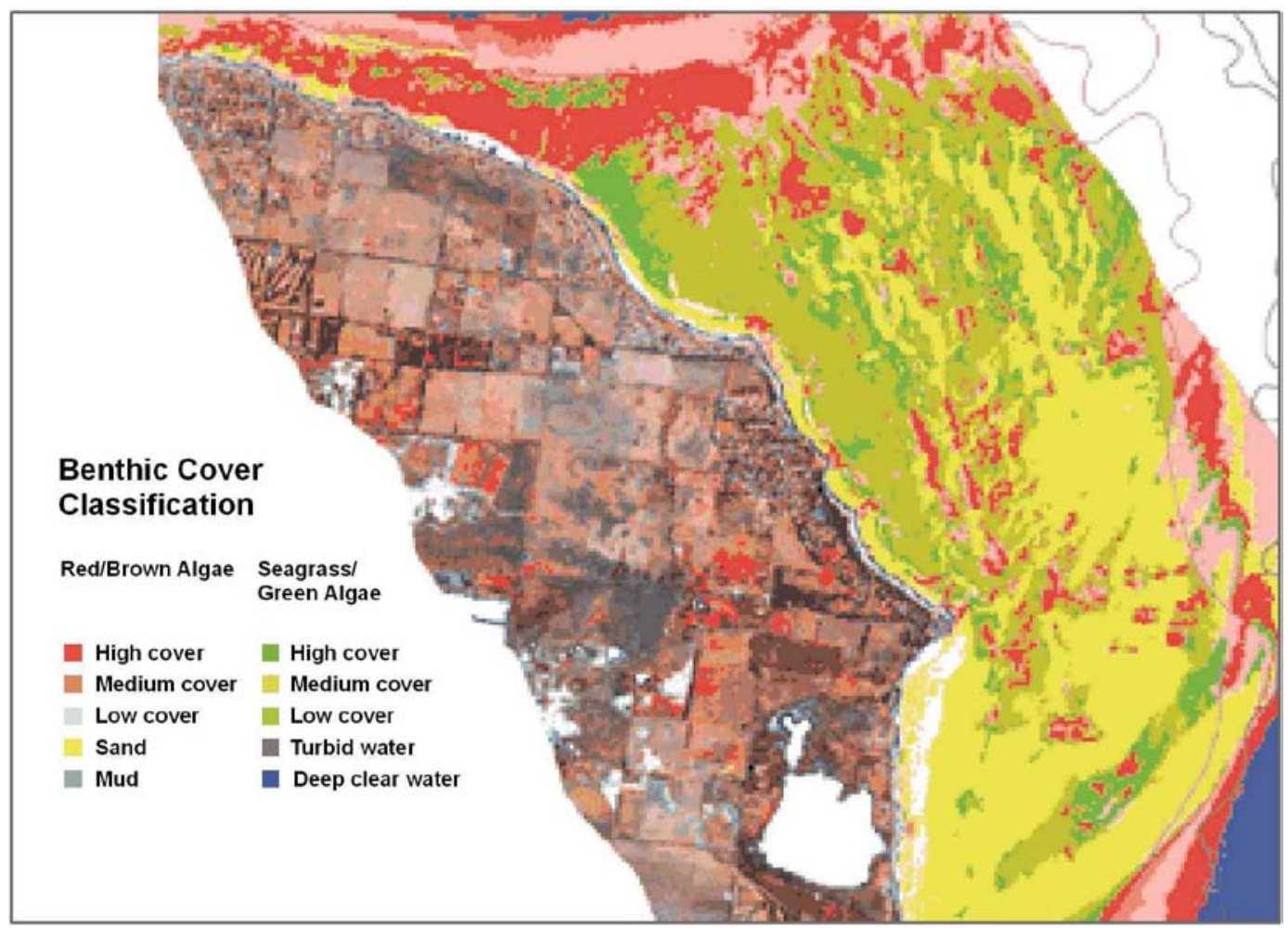

Figure 7. Benthic cover classification mapped by CASI (from Anstee et al. 1997).

\section{Acoustic listening device}

Researchers at the ERDC Geotechnical and Structures Laboratory used a rather simple waterborne technique to determine the presence of gravel on the bed in the Arkansas River. Basically, chains were deployed from a boat and dragged along the bottom of the channel. Observers on the boat listened to the sounds made by the dragging chain and were easily able to distinguish the sound of the chain on sands versus that on gravels.

\section{Single-beam acoustic systems}

Remote sensing acoustic techniques can be used to classify the composition of the subaqueous bed material in a river by processing the acoustic return signals from a standard single-beam echo-sounder. These systems work by discriminating acoustic differences of the various bed materials, such as mud, sand, gravel, and bedrock.

Two commercially available single-beam acoustic systems that have been used extensively are the RoxAnn and the Quester Tangent's QTC-View. A brief discussion of each of these follows. 


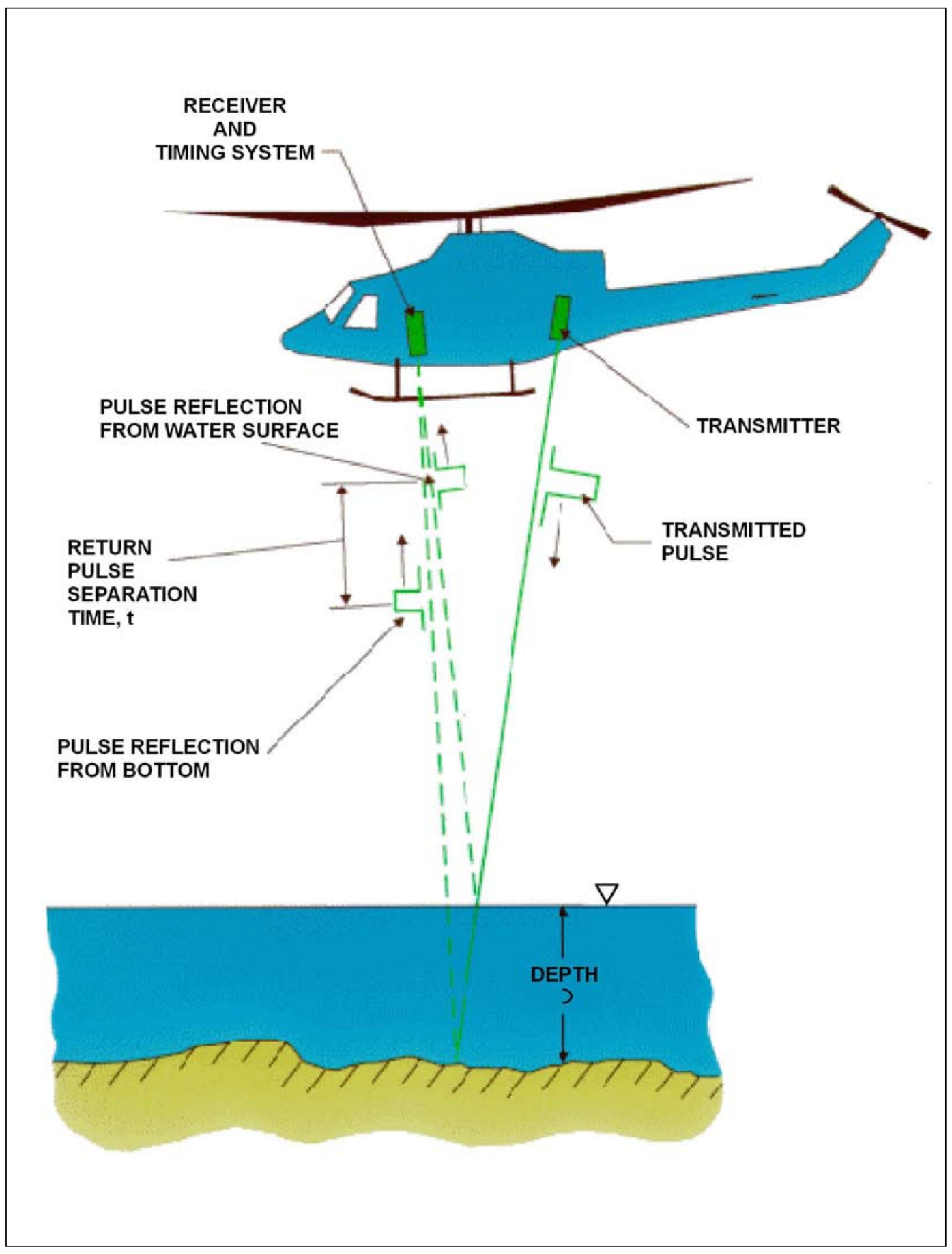

Figure 8. The SHOALS system (from Lillycrop et al. 1996). 


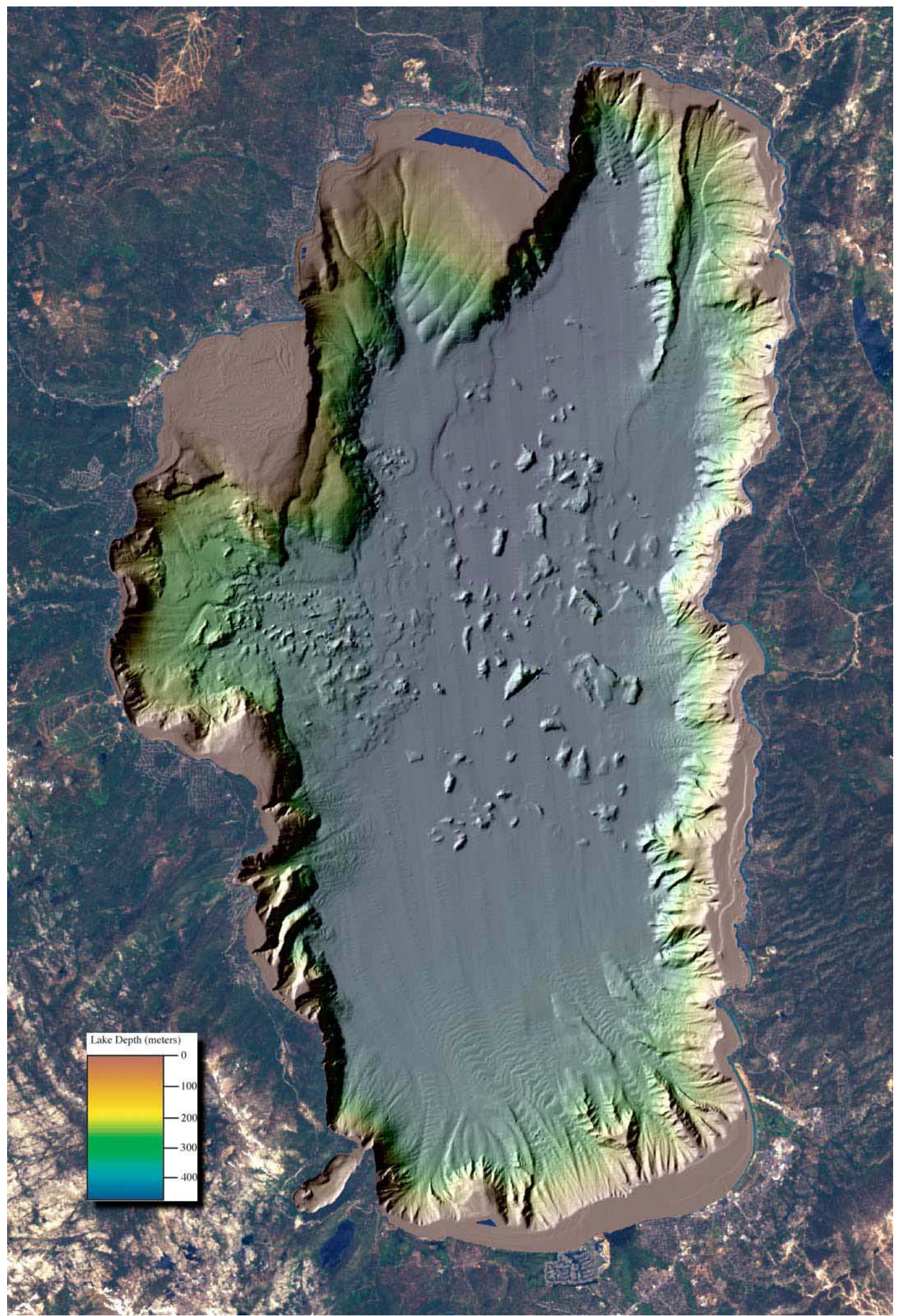

Figure 9. SHOALS application of Lake Tahoe area (U.S. Geological Survey 2000). 
The RoxAnn system is manufactured by Marine Micro Systems of Aberdeen, Scotland. Detailed descriptions of RoxAnn are provided in Burns et al. (1985) and Chivers et al. (1990). RoxAnn measures the first and second echo returns and uses these to determine the bed material composition (Kvitek et al. 1999). The first echo comes directly from the channel bed while the second echo is reflected off the channel bed and the water surface. RoxAnn uses these two echoes to estimate the roughness and hardness of the channel bottom. The results from RoxAnn must be coupled with ground-truth data to develop a classification model that can be used to predict bed materials at other sites.

Single-beam acoustic systems have been used predominantly in the coastal marine environments. However, the RoxAnn system was used by the U.S. Geological Survey to classify bed material in the Lower Bad River, WI, complex (Cholwek et al. 2005). The portion of the Lower Bad River surveyed began at Lake Superior and extended upstream $9.6 \mathrm{~km}$. Figure 10 is an example of the mapped substrate types in the Lower Bad River as determined by use of the RoxAnn system. This example shows the utility of the RoxAnn system to distinguish between clay, clay/ sand, and sand in a riverine environment.

QTC-View is a single-beam acoustic system manufactured by Quester Tangent Corporation of Sydney, BC (Kvitek et al. 1999). A detailed description of QTC-View is provided in Collins et al. (1996). QTC converts the echo from analogue to digital form and then analyzes the data using a large number of algorithms for wave form analysis (Collins et al. 1996; Collins and McConnaughey 1998). QTC uses existing echo sounder transducers but, unlike RoxAnn, does not use the second echo. The algorithms used in QTC-View and their application to the echo are considered commercially sensitive (Davies 2001). QTC-View displays three windows, as shown in Figure 11. The first window displays the reduced vector (Q) space, the second window displays the track plot and classification, and the third window displays the seabed profile classification.

RoxAnn and QTC-View have been shown to be useful tools for subaqueous bottom substrate classification (Kvitek et al. 1999). In both cases, groundtruthing is essential for reliable results. The advantages and disadvantages are listed below. 


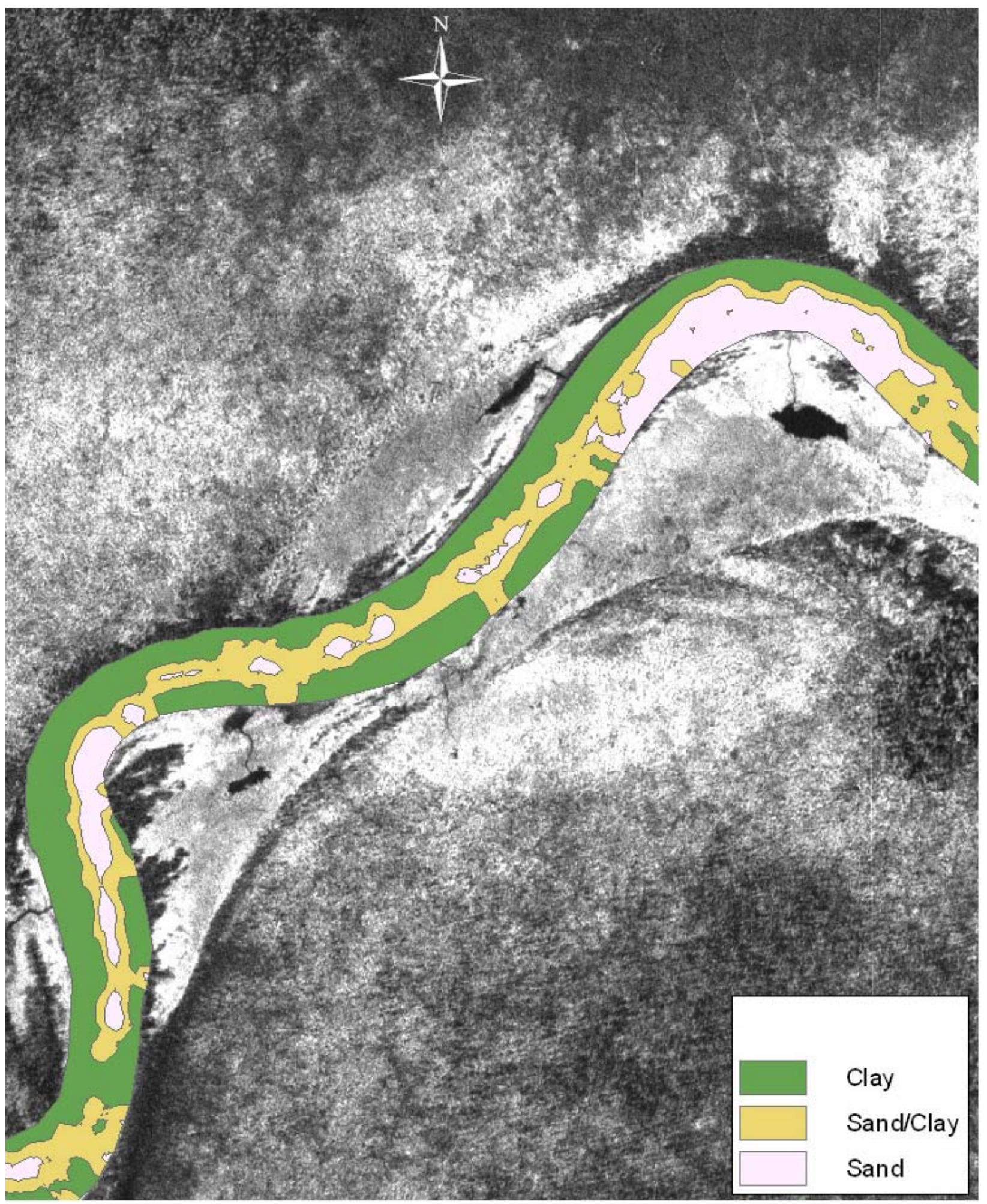

Figure 10. Example showing mapped substrate types in the Lower Bad River (Cholwek et al. 2005). 


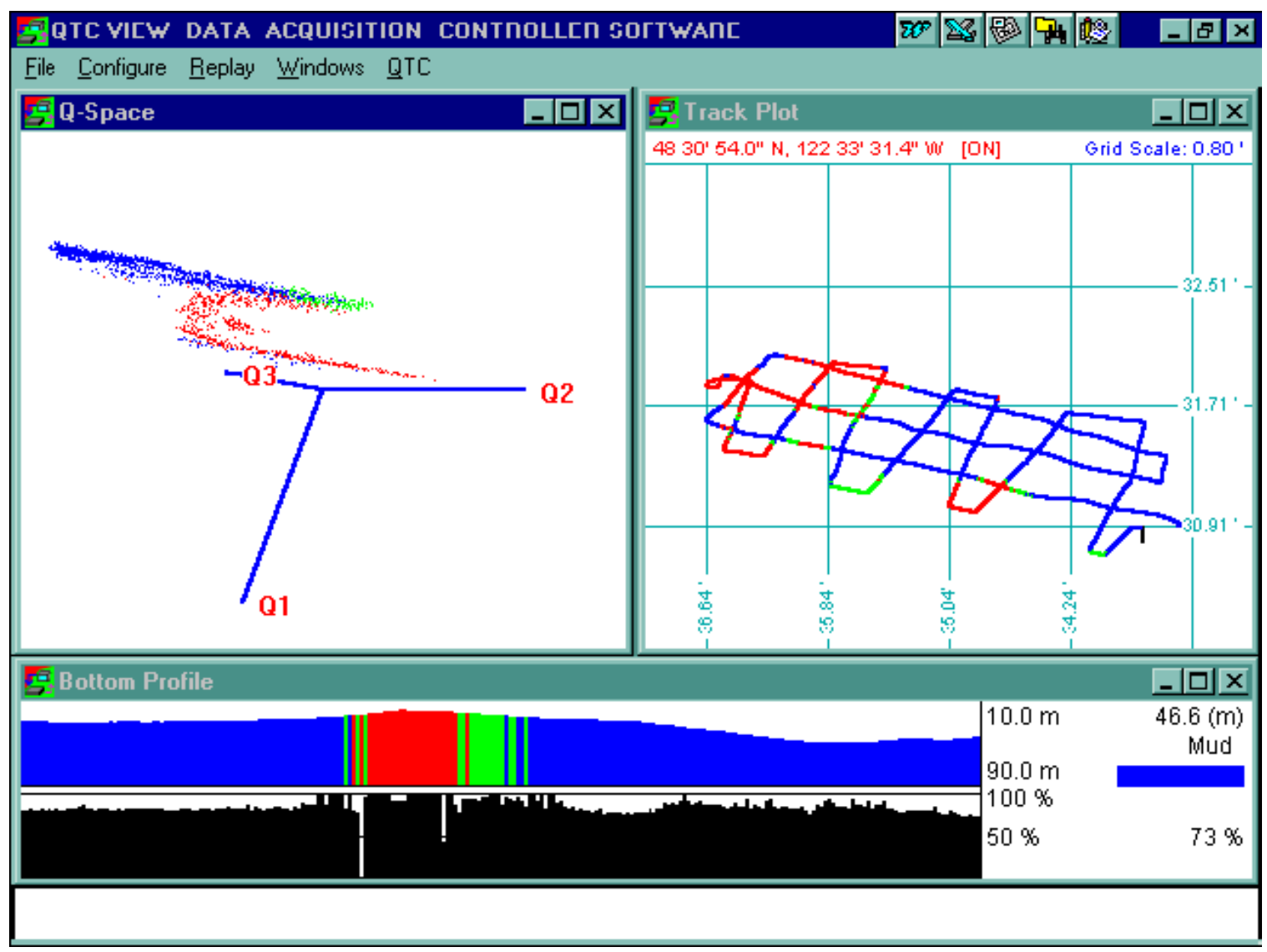

Figure 11. QTC-View window displays (Kvitek et al. 1999).

\section{Advantages}

- Acoustic Ground Discrimination Systems (AGDS) are relatively inexpensive compared with other acoustic techniques.

- The quantity of data produced, which is less than that of many other acoustic systems, facilitates data handling and analysis.

- AGDS can be deployed from a variety of vessels.

- Large areas can be surveyed.

Disadvantages

- AGDS do not give a complete coverage of the seafloor because data are acquired essentially from points directly under the survey vessel as it tracks over the survey area.

- Wide-beam width results in large acoustic footprints in deep water.

- The quality of data is subject to the effects of poor weather conditions and changes in acoustic properties, such as tide and suspended load, perhaps more so than other acoustic systems. 
The first two disadvantages mean that the resolution of these systems is poor compared with swath systems. Although close-track spacing can increase resolution, it is unlikely that a survey will result in a resolution greater than about $25 \mathrm{~m}$.

\section{Side-scan sonar}

Side-scan sonar is the only technology capable of producing continuous coverage imagery of the seafloor or channel bottom surface at all depths (Kvitek et al. 1999). This capability gives swath systems, such as side-scan sonar, a distinct advantage over single-beam acoustic systems when large areas of a channel bed must be mapped. A comprehensive review of sidescan technology is provided by Blondel and Murton (1997). Side-scan systems are typically mounted on a tow vehicle (referred to as a towfish) pulled behind the vessel (some may be mounted on the hull of the boat), and they insonify a swath on both sides of the survey line. Transducers send out sonar signals in pulses across the bed of the channel and receive the sound reflected off the bottom or off objects (sunken barges, etc.). Side-scan sonar has been used successfully for years to capture images of subaqueous features in river systems and also has some capability for distinguishing between different bed material types, such as muds, sands, gravel, and bedrock. Another advantage of side-scan sonar is that it can map large areas of the channel bed.

Side-scan sonar systems produce an immense amount of data that must be processed. Machine-image texture mapping is a recent advance in sidescan sonar systems that has increased the utility of these systems in discriminating bed material types (Tamsett 2001). This classification is objective and consistent, while human classification is subject to inconsistency in interpretation and subjectivity. Machine-image texture classification also allows for the processing of data over large areas in a timely manner. The utility of machine-image texture mapping is illustrated by the comparison of the side-scan results shown in Figures 12 and 13. Figure 12 shows a typical side-scan image of a seabed containing exposed rock scarps. The side-scan image provides a good view of the channel bed topography, but no bathymetry data or information about the composition of the bed. Figure 13 shows the classified image corresponding to the sidescan sonar image in Figure 12. As shown by this comparison, the image classification provides much greater detail with respect to the composition of the bed. 


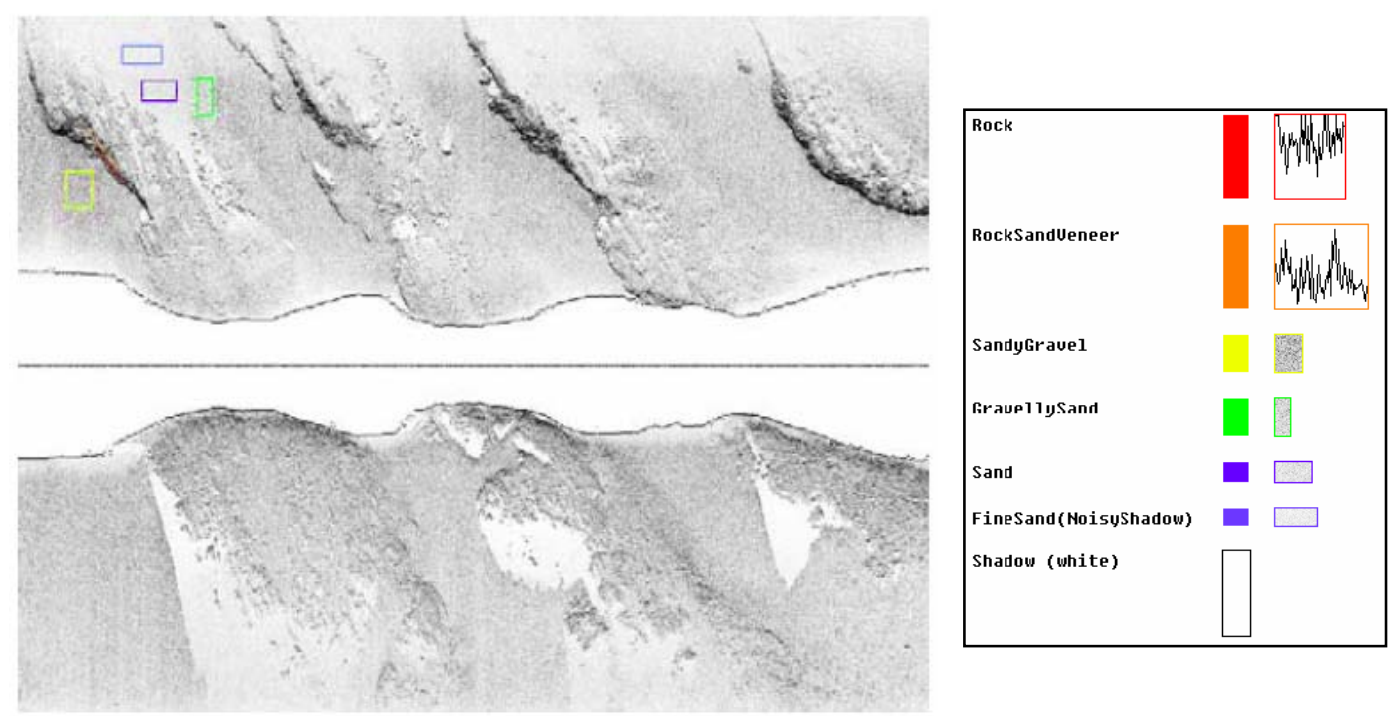

Figure 12. Side-scan image of seabed with rock scarps (from Tamsett 2001, with permission: Kongsberg GeoAcoustics).

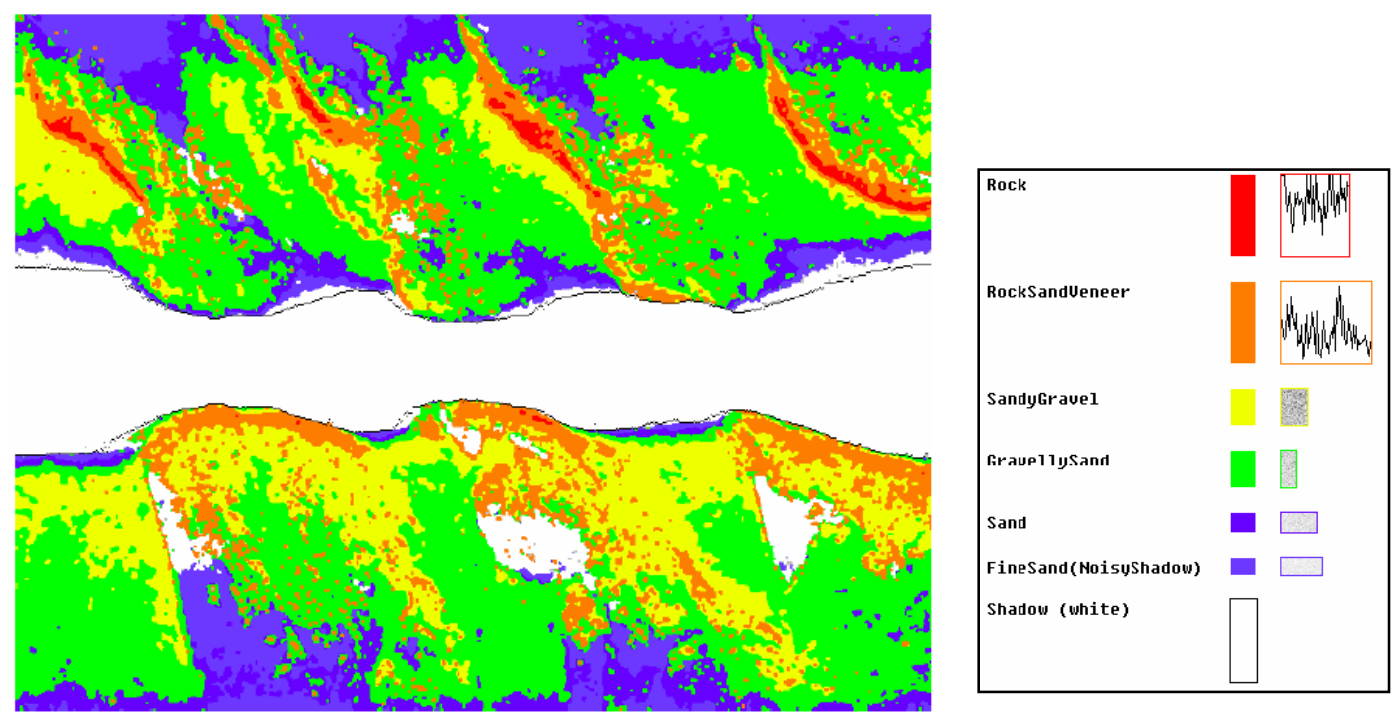

Figure 13. Classified image showing rock scarps (from Tamsett 2001, with permission: Kongsberg GeoAcoustics).

The ERDC Coastal and Hydraulics Laboratory (CHL) recently purchased GeoAcoustics Company's GeoSwath Plus hardware and software system, which provides multibeam swath bathymetry and side-scan mapping. GeoSwath Plus uses a machine-image texture mapping software called GeoTexture for side-scan sonar image processing, texture mapping, and classification (GeoAcoustics 2008). The classified image in Figure 13 was processed by GeoTexture. GeoSwath Plus has been used successfully to map bed composition on numerous coastal, marine, and riverine applications. 


\section{Subbottom sampling}

In the previous section, techniques that have the potential to classify material on the channel bed were discussed. However, as noted, the exposure of gravel along the channel can be transitory on a dynamic river, such as the Lower Mississippi River. In fact, the burial of a gravel deposit by only a few centimeters or less of sand would render it undetectable by any of the methods reviewed in the section "Subaqueous bed materials." For this reason, it is important to determine if there are subbottom profiling techniques capable of reliably detecting buried gravel deposits.

Subbottom profiling uses acoustic impedance (acoustic velocity and material density) and seismic refraction to identify different sediment layers beneath the bed-water interface. Subbottom systems generally work at lower frequencies than the single-beam systems to achieve greater penetration into the bed. They also generate a range of wavelengths or frequencies with each acoustic pulse, rather than a single wavelength pulse. ${ }^{1}$ Subbottom sonar systems send a sound impulse vertically downward to the channel bed, and a receiver monitors the return signal. Some of the signal will penetrate the channel bed until it encounters the boundary between two acoustically different materials.

In subbottom profiling there is a trade-off between penetration depth and resolution. Higher frequency systems have greater resolution but less penetration. Lower frequency systems have a greater penetrating ability but lose resolution. Subbottom profiling is the only acoustic technique capable of detecting and mapping a sequence of strata below the channel bottom. However, subbottom systems have a narrow swath width, so continuous coverage of large areas may be time consuming and costly. For a more detailed review of subbottom profiling, the reader is referred to Ballard and McGee (1994), Caufield and Yim (1983), Hamilton (1970, 1972), and McGee et al. (1994).

A comprehensive subbottom profiling on a lower portion of the Lower Mississippi River was conducted by Murphy (1983). He conducted continuous acoustic subbottom profiling for 100 miles of the river near Lake Providence, LA, and from just downstream of Greenville, MS, to just

\footnotetext{
1 Personal communication, T. N. Waller, ERDC Coastal and Hydraulics Laboratory, Vicksburg, MS.
} 


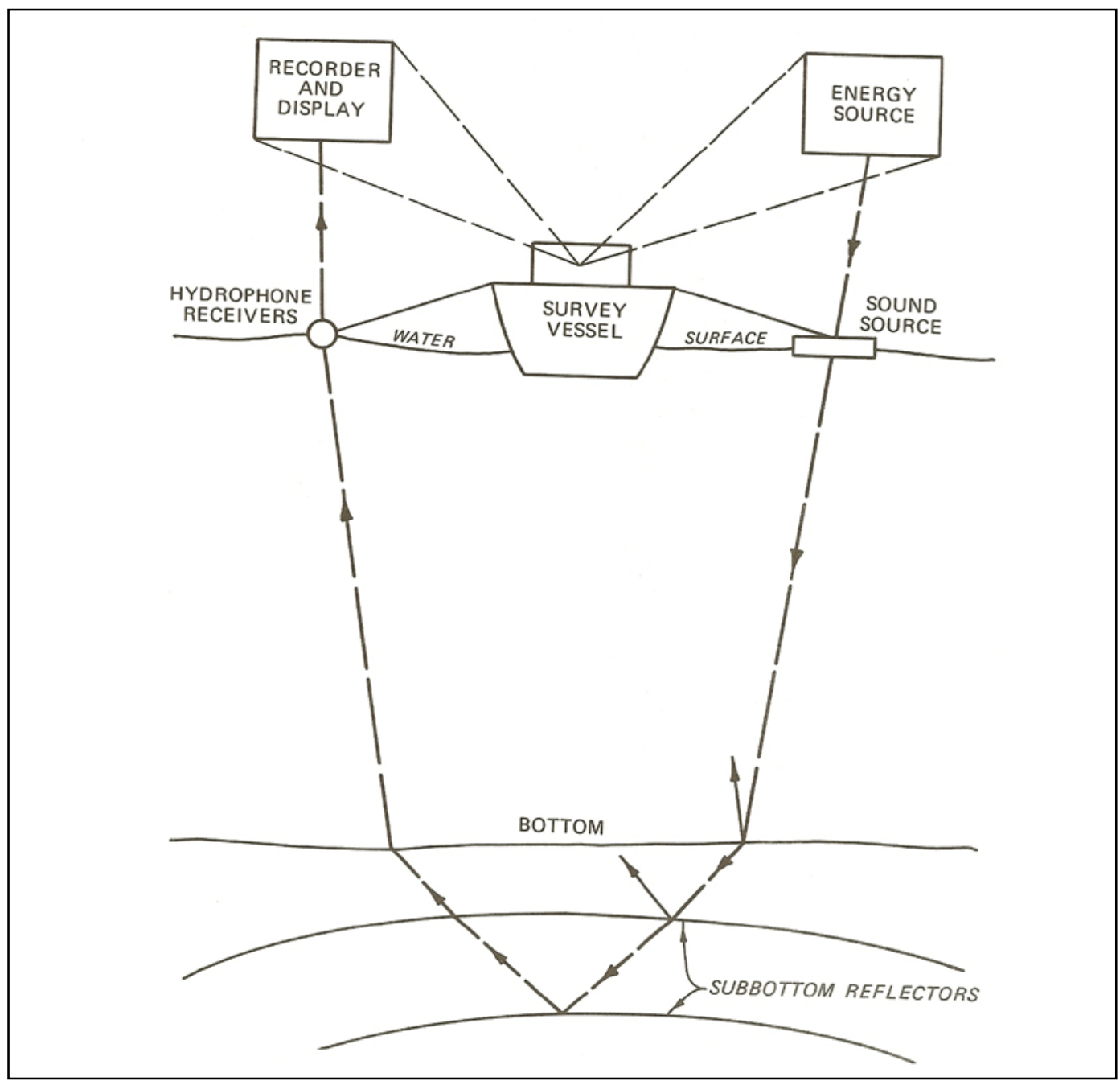

Figure 14. Elements of the acoustic subbottom profiling equipment (Murphy 1983).

upstream of Rosedale, MS. Figure 14 shows the elements of the subbottom combined with other geologic and topography data to map the profiling technique used by Murphy (1983). The subbottom data were location and extent of various geologic horizons beneath the channel, especially the strata, Tertiary ( 65 million to 1.8 million years before present) in age, underlying river alluvium.

Figure 15 shows a typical subbottom profile on the Mississippi River between RM 526.3 and RM 530.4. Murphy (1983) noted that the horizon representing the top of the Tertiary strata (base of the river alluvium) was easy to distinguish if the alluvium was penetrated. He also noted that other horizons within the alluvium acted as good reflectors that resemble the Tertiary strata. In these cases, data from borings were analyzed to 


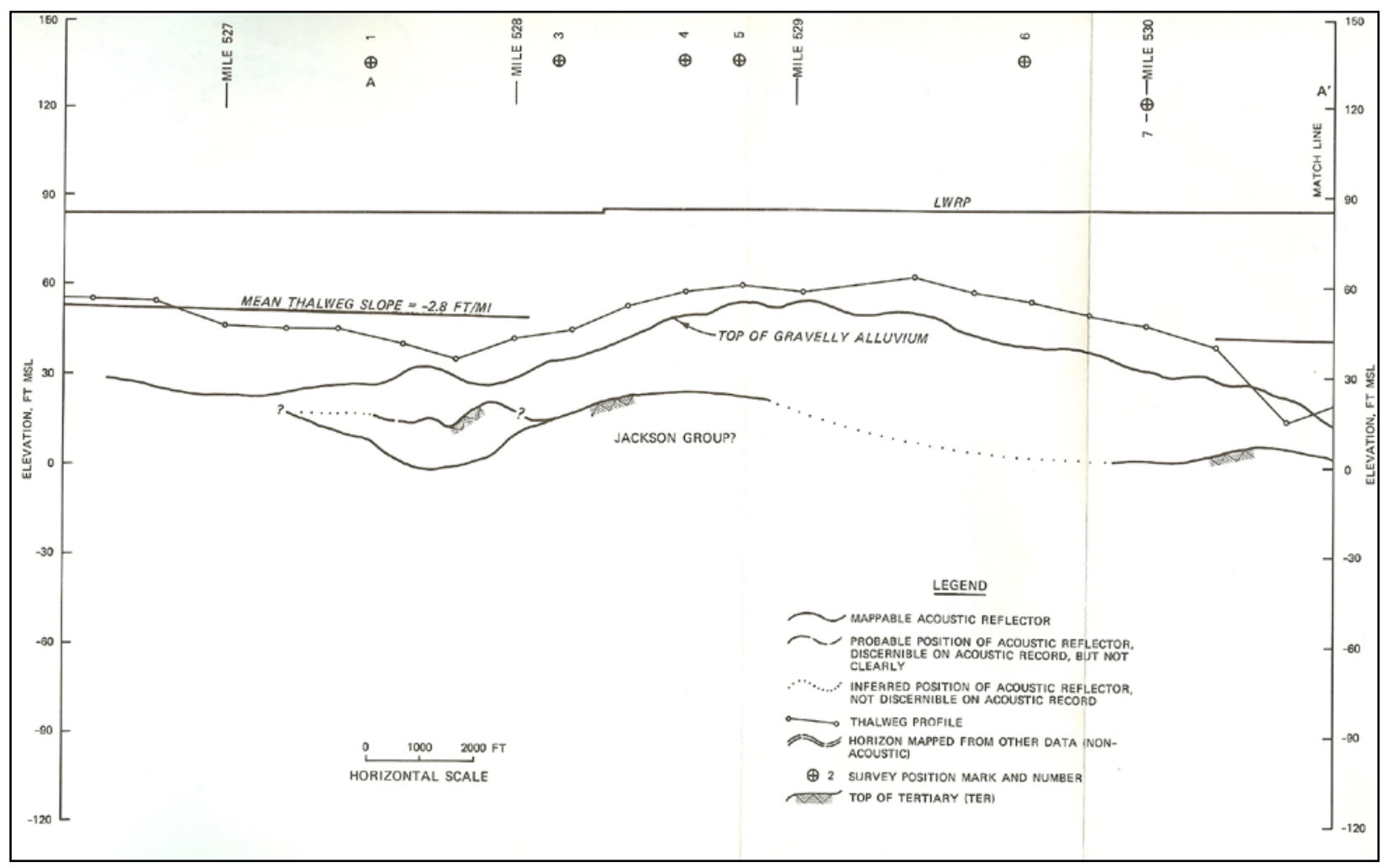

Figure 15. Subbottom profile between RM 526.3 and RM 530.4 (Murphy 1983).

determine whether the reflector was a Tertiary boundary. One of the horizons observed within the alluvium was the tops of buried gravelbearing or coarse-grained strata underlying fine-grained sediments (Figure 15). This observation is significant for the present study because it illustrates that it is possible for gravel deposits to be detected with the subbottom equipment.

Recent advancements in subbottom system hardware and analytical software provide greater capability in classifying subbottom horizons. Subbottom profiling appears to have the potential to classify buried gravel deposits on the Lower Mississippi River. However, as with all remote sensing techniques discussed, obtaining good ground-truth data is essential if reliable results are to be expected. Unfortunately, groundtruthing subsurface material poses a greater challenge than does surface material. Direct observations of these strata will require coring of the channel, which can be both time consuming and costly. However, it may be possible to obtain ground-truth data in selected areas and then use these data to develop a classification scheme that could be applied to other areas that do not have ground-truth data. As shown by Murphy (1983), 
analyses of existing borings adjacent to the channel can also be used to help classify the various strata.

\section{Terrestrial geophysical techniques}

This study is aimed at determining the location and extent of gravel deposits in the Lower Mississippi River that may provide spawning habitat for the pallid sturgeon. Because of this goal, the focus has been on waterborne techniques that have the ability to classify subaqueous (underwater) sediments. However, there are some terrestrial geophysical techniques that may prove useful in identifying the presence and depth of gravel strata. These techniques should prove complementary to subbottom systems that address the underwater portion of the gravel strata. It is envisioned that terrestrial geophysical techniques could be used in low-water conditions on exposed bars in the river. Results from these investigations could then be extrapolated to the underwater portion of the channel.

A number of terrestrial geophysical techniques are capable of characterizing subsurface sediment types. Geophysical techniques have been used for many years to characterize subsurface material. These techniques have typically been used to provide information on the following: (1) aerial extent and thickness of a sediment deposit; (2) thickness of overburden; (3) depth to water table; (4) critical geologic contacts; (5) location and correlation of geologic features; (6) structure, such as strike and dip, of geologic strata; and (7) presence of subsurface cavities. A detailed discussion of the use of geophysical techniques used to characterize sand and gravel deposits is provided by Lucius et al. (2007). Techniques include seismic refraction and reflection, direct current (DC) resistivity, ground penetrating radar (GPR), time domain electromagnetism (TDEM), and frequency domain electromagnetism (FDEM). A brief summary of these techniques follows.

Seismic refraction and reflection depend on the transmission of strain energy as an elastic or seismic wave through the medium (Lucius et al. 2007). Seismic waves are generated at or near the ground surface. For example, they are created by striking a plate with a sledgehammer or by setting off a small explosive charge in a shallow hole. Seismic wave detectors (geophones) convert ground vibrations into an electrical signal. Interpretation of subsurface boundaries is based on variation of seismic velocity that results from changes in elastic properties or density of the materials. 
An example of processed seismic reflection data showing layers within the alluvium and the top of the bedrock is shown as Figure 16.

In a typical DC resistivity method, four metal stake electrodes are driven into the ground. An electrical current is introduced into two of the stakes, and the electrical potential is measured between the other two electrodes (Lucius et al. 2007). The representative resistivity of the subsurface material is then determined. Data collection advances in the 1990s have allowed the use of hundreds of electrodes. Lucius et al. (2007) list two limitations of DC resistivity that may limit its applicability to gravel detection in the Lower Mississippi River. First, different materials, such as sands and gravels, often have similar or the same resistivity, making it difficult to distinguish between them. Second, water content can also affect measured resistivity. For instance, it may be difficult to distinguish between electrically conductive clay and nonconductive sand that has water occupying the pore space. Figure 17 shows interpretations of resistivity models for multi-electrode data collected over a sand and gravel deposit (Lucius et al. 2007).

Ground penetrating radar was developed commercially in the 1970s for shallow-earth exploration. GPR is an electromagnetic method that depends on the propagation of high-frequency (10-MHz to 3-GHz) electromagnetic energy in the ground (Lucius et al. 2007). Different subsurface materials are detected when the electromagnetic wave encounters a change in electromagnetic properties, and some of the wave is reflected back to a receiving antenna. An example of GPR data interpretation is shown as Figure 18. Ground electrical conductivity is the major factor limiting the GPR depth of investigation. According to Lucius et al. (2007), if the ground conductivity is high (above 30 to $40 \mathrm{mS} / \mathrm{m}$ ), the survey depth may be much less than $1 \mathrm{~m}$. Wet soil is generally conductive; therefore, GPR generally works better in dry material. Additionally, GPR usually cannot distinguish between sands and gravels unless there is additional geologic information.

Electromagnetic (EM) techniques measure electrical conductivity of a soil and then relate conductivity to soil properties. Two EM techniques that are commonly used are time domain electromagnetic and frequency domain electromagnetic. Both techniques operate by inducing an electrical current into the soil and measuring the electrical conductivity of the soil. A detailed description of both of these techniques is provided by 


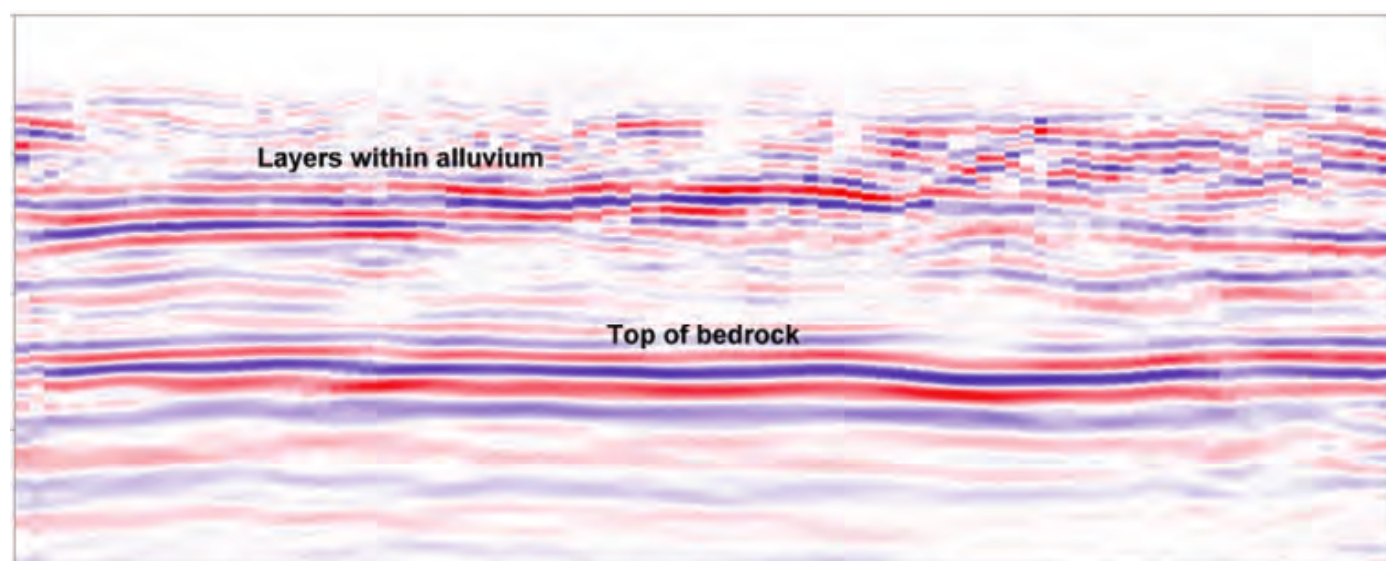

Figure 16. Seismic reflection data showing layers within the alluvium and the top of the bedrock (Lucius et al. 2007).

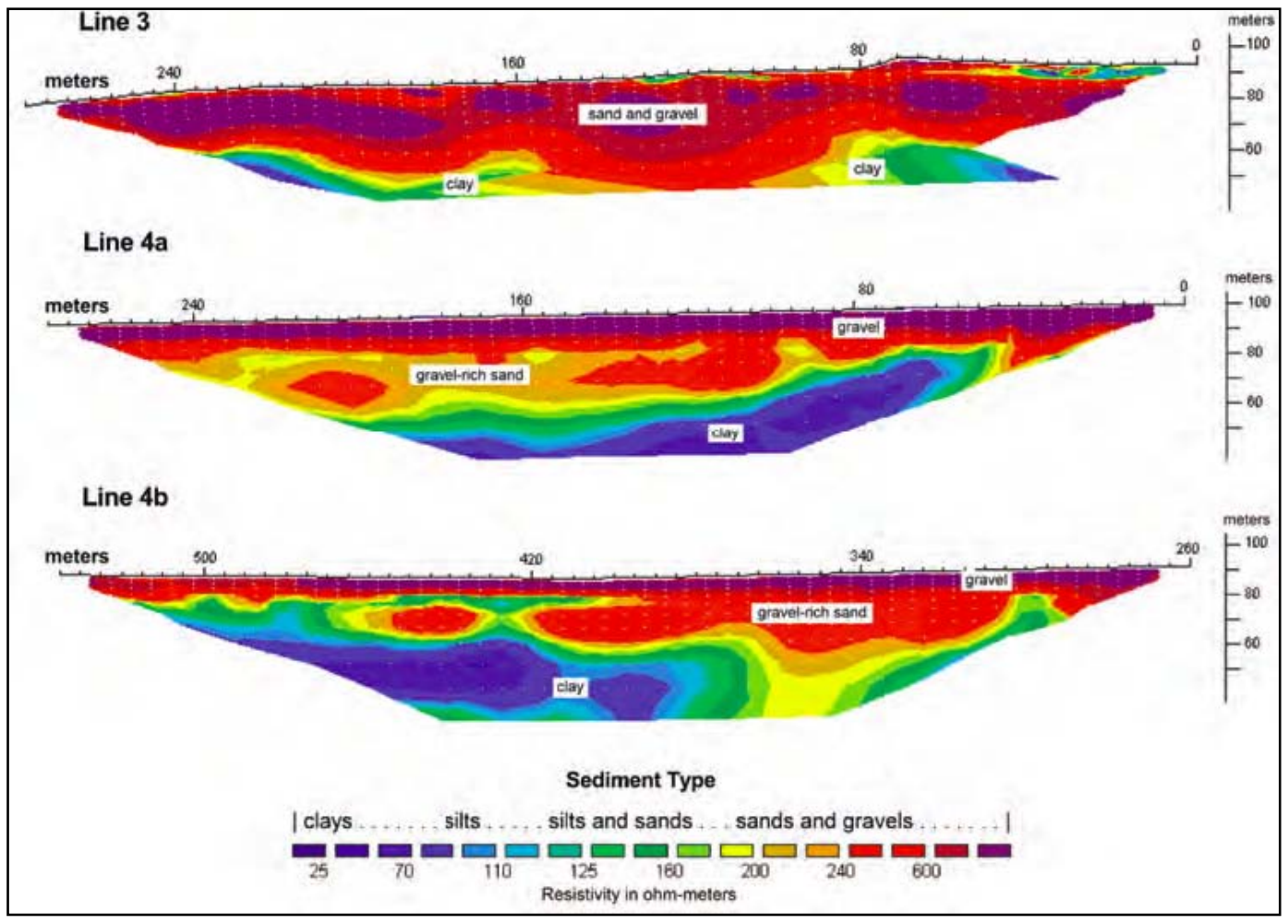

Figure 17. Interpretations of resistivity models for multi-electrode data collected over a sand and gravel deposit (Lucius et al. 2007).

Lucius et al. (2007). Examples of TDEM and FDEM are shown as Figures 19 and 20, respectively. As with DC resistivity and GPR, the measured conductivity may be substantially different from the true conductivity in highly conductive ground. 


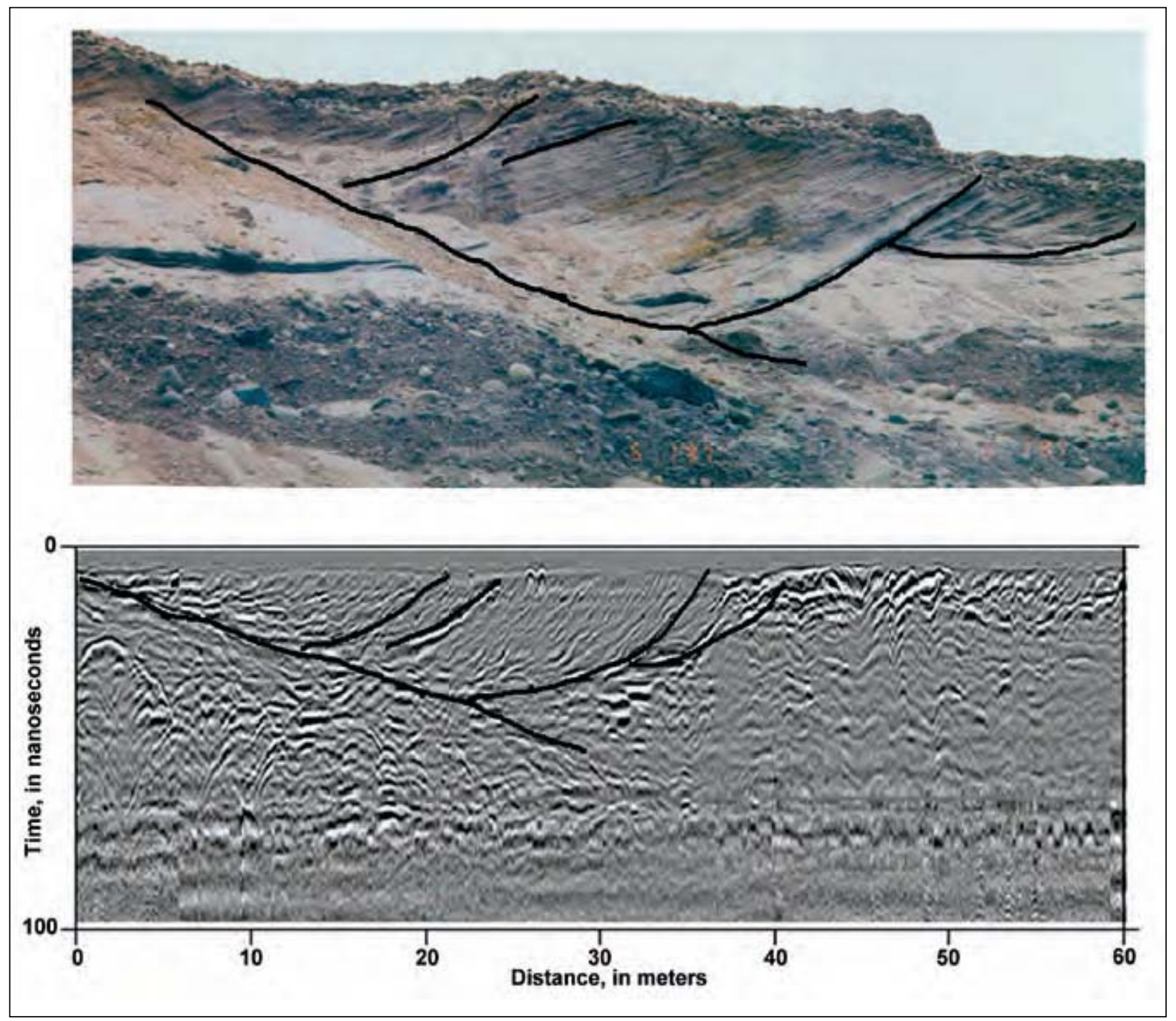

Figure 18. Interpretation of GPR data collected near an active sand and gravel quarry (Lucius et al. 2007).

It is important to note that sand and gravel are treated as a single unit in the Lucius et al. (2007) study, and the techniques are evaluated with respect to their ability to distinguish a sand and gravel unit from other units such as clay, sandstone, shale, or other rock. Therefore, their capability to distinguish sand from gravel has not been documented. The ability of these systems to function in the riverine environment where the water content of the ground may mask contrasts in resistivity/ conductivity is also not clear. Therefore, additional testing is required to determine how effective these systems would be for classifying gravel deposits in a river environment. 


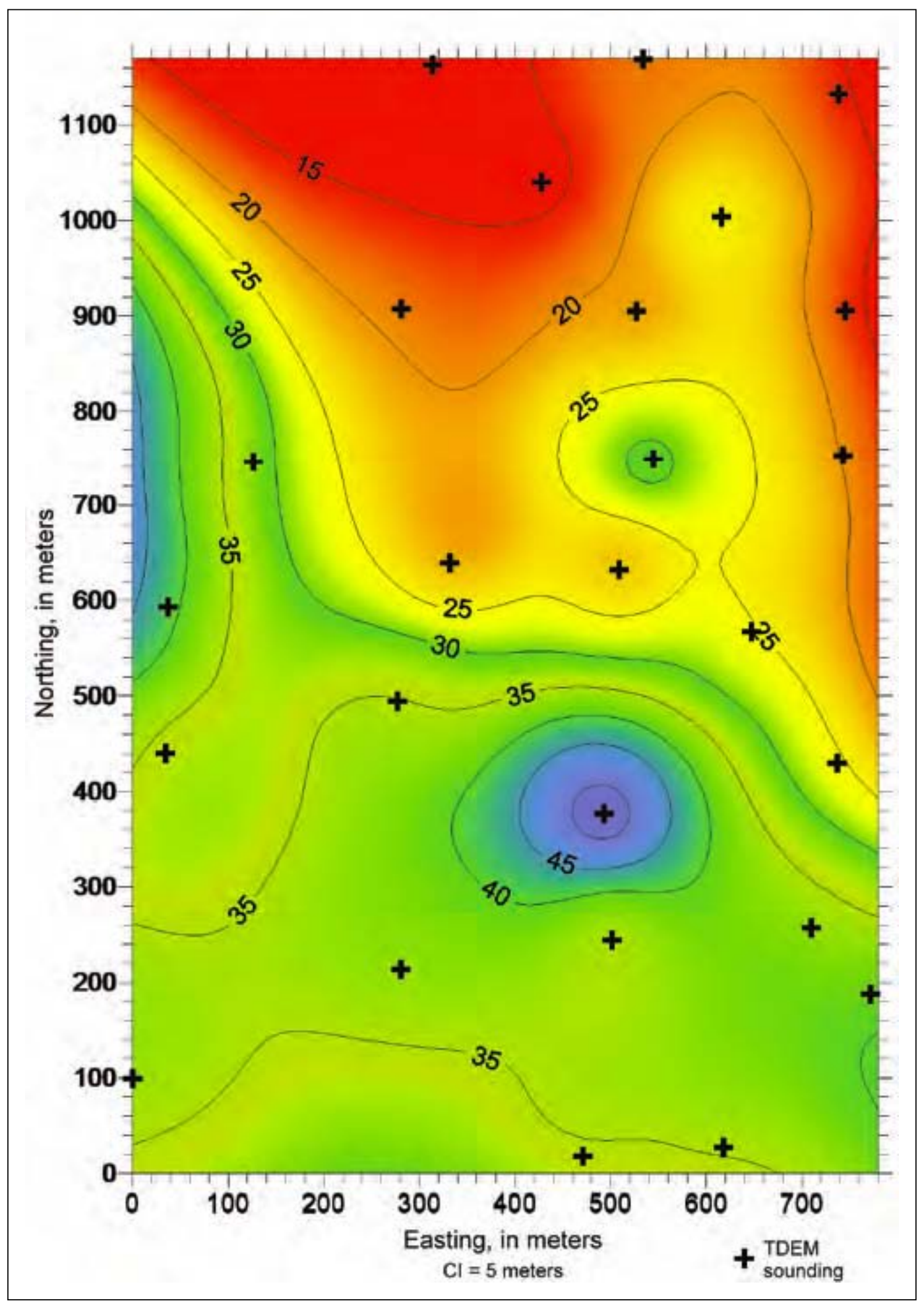

Figure 19. Bedrock depth in meters determined by use of TDEM soundings on an alluvial floodplain (Lucius et al. 2007). 


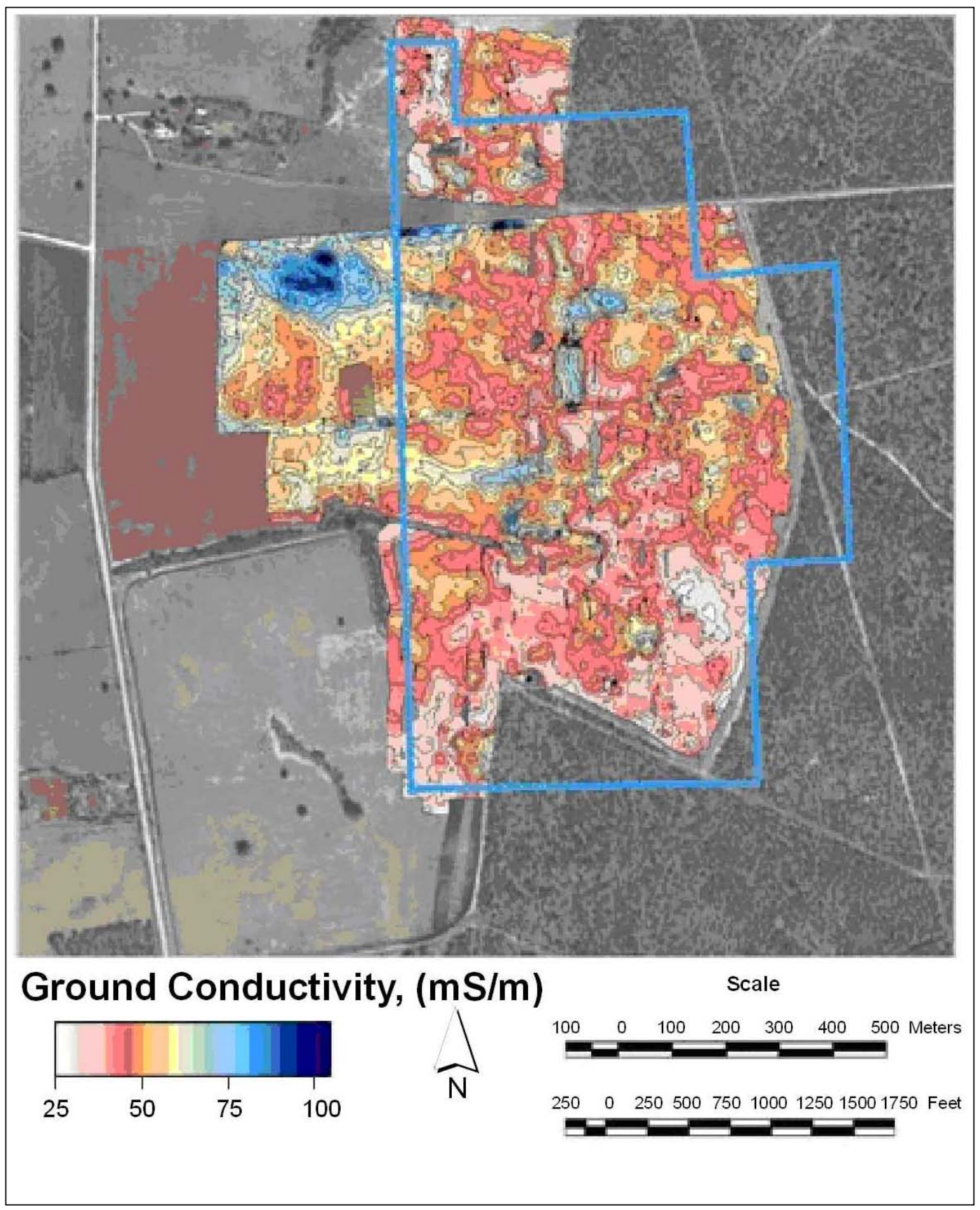

Figure 20. Contour map of ground conductivity generated by FDEM (from Green 2007, with permission). Fine-grained sediments, such as clay and silt, are electrically conductive and are shown as blue, green, and yellow. Porous grained sediments, such as sands and gravels, are electrically resistive and are shown as orange, red, and pink. 


\section{Numerical Analysis of Gravel Bar Morphology}

Acquiring the capability to classify gravel deposits in the river is an important first step in developing an understanding of the relationships between these features and the spawning habitat requirements of pallid sturgeon. However, gravel deposits are extremely dynamic features, and their exposure and their ability to serve as a spawning habitat are spatially and temporally highly variable. This extreme variability is illustrated in Figure 21, which shows the changes in bed topography between 2000 and 2001 and between 2001 and 2002 for a portion of the Mississippi River dike field near Lake Providence, LA. Bed scour is depicted by the blue colors, while fill is depicted by red colors. The darker the color, the more severe the scour or fill. The lighter colors (light greens, pink, and beige) reflect areas with little change. Examination of Figure 21 shows that deposition was the dominant process between 2000 and 2001, while scour is more pronounced between 2001 and 2002. Annual variations in scour and fill patterns, such as those depicted in Figure 21, are well documented throughout the Lower Mississippi River (Biedenharn et al. 2000).

Predicting the bed changes on a large, dynamic river such as the Mississippi presents serious challenges. One approach that may provide insight into the stochastic nature of these gravel deposits is the use of two-dimensional (2-D) sediment transport modeling. To provide usable results, the model will have to make long-term ( 5 to 30 years) simulations quickly so that a wide variety of hydrographs can be analyzed. Hydrographs will be selected to reflect a wide variety of antecedent conditions and flow and sediment characteristics. This will not be a deterministic approach that will predict the exposure of gravel at a certain time. Rather, it will provide a probability that gravel is exposed at certain times of the year at a specific location. Unfortunately, existing 2-D models do not have this long-term capability. However, a proof-of-concept model of this type of tool was successfully completed in fiscal year (FY) 07 by ERDC CHL. This model is now being tested on the Mhoon Landing reach on the Mississippi River, and it is anticipated that a working-level model with the capability to conduct long-term simulations will be available in FY 11. 


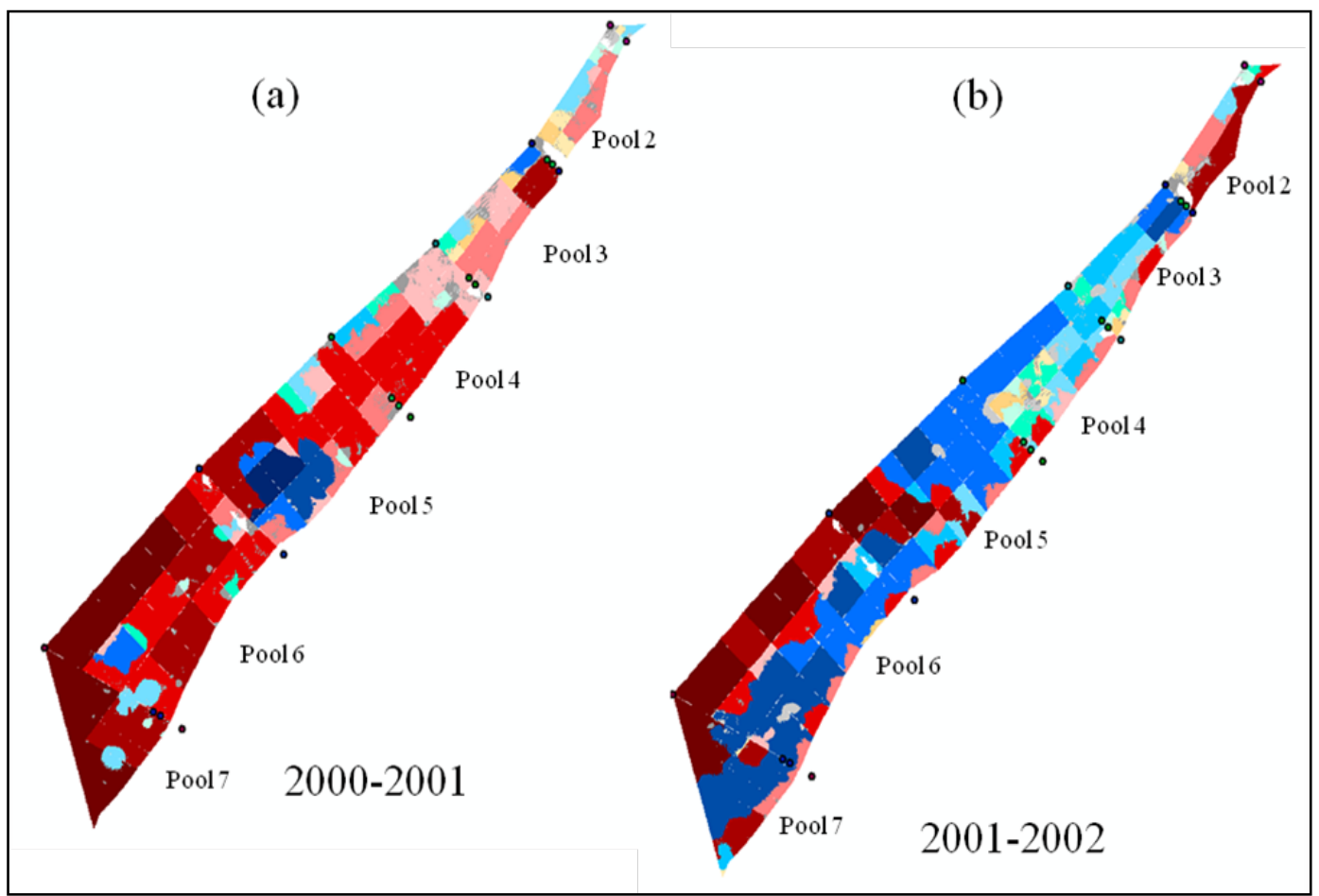

Figure 21. Bed topography changes in a dike-controlled channel. Bed scour is depicted by the blue colors while fill is depicted by red colors. The darker the color, the more severe the scour or fill. The lighter colors (light greens, pink, and beige) reflect areas with little change. 


\section{Summary}

Each of the techniques discussed in the preceding sections has its own merits and limitations that must be considered when researchers select the most appropriate methods to identify and map gravel deposits in the Lower Mississippi River. Table 1 provides a comparison of the merits of each of the techniques discussed in this report. In Table 1, Column 1 (Target Material) refers to the type of material that the technique is intended to detect. Column 2 (Cost) describes the relative cost to apply the technique (low or high). The actual cost is dependent on a number of factors, such as the extent of the area to be covered, the complexity of the equipment, the need to purchase or rent the equipment, and deployment and operational factors. Consequently, it is difficult to assign a quantitative cost to the techniques. Techniques identified as low cost were generally the low-technology approaches, while the more technologically sophisticated methods were rated as high cost. Column 3 (Operational Difficulty) refers to complexity and time involved in deploying the device and in postprocessing analysis. Operational difficulty directly affects the cost in Column 2. Column 4 (Subsurface Capability) refers to the ability of the technique to detect material beneath the surface of the streambed. Column 5 (Riverine Application) refers to whether the technique has been used in a riverine environment. Column 6 (Gravel Classification) assesses the ability of the technique to distinguish gravel from sands, clay, rock, or other materials. Column 7 (Spatial Coverage) addresses the relative size of the areas of the river that can be covered. Column 8 (Reliability) provides a general assessment of the degree of confidence for the technique to be successful in the Lower Mississippi River. Reliability is graded on a scale from 1 to 5 , with 5 having the highest reliability and 1 the lowest. 
Table 1. Comparison of potential gravel detection techniques.

\begin{tabular}{|c|c|c|c|c|c|c|c|c|}
\hline \multirow[b]{2}{*}{ Technique } & \multicolumn{8}{|c|}{ Category } \\
\hline & $\begin{array}{c}1 \\
\text { Target } \\
\text { Material }\end{array}$ & $\begin{array}{c}2 \\
\text { Costa }^{a}\end{array}$ & $\begin{array}{c}3 \\
\text { Operational } \\
\text { Difficulty }\end{array}$ & $\begin{array}{c}4 \\
\text { Subsurface } \\
\text { Capability }\end{array}$ & $\begin{array}{c}5 \\
\text { Riverine } \\
\text { Application }\end{array}$ & $\begin{array}{c}6 \\
\text { Gravel } \\
\text { Classification }\end{array}$ & $\begin{array}{c}7 \\
\text { Spatial } \\
\text { Coverage }^{b}\end{array}$ & $\begin{array}{c}8 \\
\text { Reliabilityc }\end{array}$ \\
\hline Visual inspection & Exposed bars & Low & Low & None & Yes & Yes & Large & 5 \\
\hline $\begin{array}{l}\text { Electro-optical techniques } \\
\text { (LIDAR, CASI, LLS) }\end{array}$ & $\begin{array}{l}\text { Subaqueous } \\
\text { bed material }\end{array}$ & High & High & None & No & No & Large & 1 \\
\hline $\begin{array}{l}\text { Simple acoustic listening } \\
\text { Devices }\end{array}$ & $\begin{array}{l}\text { Subaqueous } \\
\text { bed material }\end{array}$ & Low & Low & None & Yes & Yes & Large & 3 \\
\hline $\begin{array}{l}\text { Single-beam acoustic } \\
\text { systems (RoxAnn, QTC-View) }\end{array}$ & $\begin{array}{l}\text { Subaqueous } \\
\text { bed material }\end{array}$ & High & High & None & Yes & Yes & Moderate & 3 \\
\hline $\begin{array}{l}\text { Side-scan sonar } \\
\text { (GeoSwath Plus) }\end{array}$ & $\begin{array}{l}\text { Subaqueous } \\
\text { bed material }\end{array}$ & High & High & None & Yes & Yes & Large & 4 \\
\hline Subbottom sampling & $\begin{array}{l}\text { Subsurface } \\
\text { material }\end{array}$ & High & High & Yes & Yes & Yes & Moderate & 2 \\
\hline $\begin{array}{l}\text { Terrestrial geophysical } \\
\text { methods }\end{array}$ & $\begin{array}{l}\text { Subsurface } \\
\text { material }\end{array}$ & High & High & Yes & Unknown & Unknown & Limited & 1 \\
\hline Analysis of existing borings & $\begin{array}{l}\text { Subsurface } \\
\text { material }\end{array}$ & Low & Low & Yes & Yes & Yes & Large & 3 \\
\hline
\end{tabular}

a Costs are relative and are generally related to the operation difficulty in Column 3.

b Spatial coverage reflects the capability of the technique to cover large areas of the river versus smaller site-specific areas.

${ }^{c}$ Reliability refers to the level of confidence in the technique, with 5 being the highest and 1 being the lowest. 


\section{Recommendations}

Based on the information provided above, it appears that the classification of the subaqueous bed material in the Lower Mississippi River may be achieved by use of direct observations and acoustic techniques. Direct observation is obviously the most reliable method but is limited to exposed areas of gravel. Therefore, it is recommended that a detailed visual inspection of the river from Cairo, IL, to Old River, MS, be conducted with focus on the identification of exposed gravel bars. This investigation should be conducted at low water, probably in the fall. A boat trip is recommended; however, the investigation may also be accomplished by helicopter. During the trip, each exposed gravel bar will be documented with GPS and the areal extent of the feature determined. This information will then be uploaded to a geographic information system for spatial recognition and visual output. Some digging and probing with hand equipment will be necessary to measure the depth of the gravel and to determine whether the exposed feature is only an armor layer. This inspection will provide only a one-time view of the gravel deposits. It must be recognized that, at other times, some of these areas will be buried while new sites previously buried will become exposed. For this reason, repeating the inspection over a period of several years will be beneficial.

The RoxAnn and QTC-View systems (single-beam acoustic systems) both appear to be viable alternatives for classifying the subaqueous bed materials. However, for covering very large areas quickly, these systems are somewhat limited because the data are essentially collected from points directly under the survey vessel or lines along the vessel track. For this reason, a swath system that provides better resolution for a larger area of the channel is preferable. GeoSwath Plus (side-scan sonar) appears to have the greatest potential to map large areas of the river. Therefore, it is recommended that a detailed evaluation using the GeoSwath Plus system be conducted at several sites on the river to evaluate its potential capabilities. One potential site is the Mhoon Landing area, where a wellestablished gravel bar has been documented by ERDC Environmental Laboratory as part of its fish studies. Another site should be selected where the actual presence and extent of the gravel deposit is less well documented. 
Both the visual inspections and the GeoSwath Plus system will provide information only about the surface bed material. To assess the potential volume of gravel available in the system, an estimate of the depth of these deposits is needed. Therefore, it is recommended that existing data from boring adjacent to the selected test sites be evaluated to provide a first approximation of the vertical extent of these features. Subbottom profiling may also provide information about the vertical extent of the gravel deposits. Therefore, it is recommended that a subbottom profiling system be applied to the selected test sites to determine the system's ability both to classify buried gravel strata and to determine the vertical extent of these strata.

The 2-D model being developed by ERDC should be applied on the gravel test sites. The information collected from the field tests can be used as data input for the model. These sites will provide a good test of the utility of the model to predict long-term changes in the exposure of the gravel deposits. 


\section{References}

Anstee, J . M., D. L. B. J upp, and G. T. Byrne. 1997. The shallow benthic cover map and optical water quality of Port Phillip Bay. Presented at 4th International Conference on Remote Sensing for Marine and Coastal Environments, Orlando, FL.

Ballard, R. F., and R. G. MoGee. 1994. Acoustic impedance for assessing subbottom conditions. In Proceedings, Second International Conference on Dredging and Dredge Material Placement. Lake Buena Vista, FL: Waterways Committee of the Waterway, Port, Coastal, and Ocean Division, American Society of Civil Engineers.

Biedenharn, D. S., L. C. Hubbard, and P. H. Hoffman. 2000. Historical analysis of dike systems on the lower Mississippi River. Unpublished report. Vicksburg, MS: U.S. Army Engineer Research and Development Center.

Blondel, P., and B. J . Murton. 1997. Handbook of seafloor sonar imagery. New York: Wiley.

Burns, D., C. B. Queen, and R. C. Chivers. 1985. An ultrasonic signal processor for use in underwater acoustics. Ultrasonics 23:189- 191.

Caufield, D. D., and Y. C. Yim. 1983. Prediction of shallow subbottom sediment acoustic impedance while estimating absorption and other losses. J ournal of Canadian Society of Exploration Geophysics 19(1):44- 50.

Chivers, R., N. Emerson, and D. Burns. 1990. New acoustic processing for underwater surveying. Hydrologic J ournal 56:9- 17.

Cholwek, G., D. Yule, M. Eitrem, H. Quinlan, and T. Doolitle. 2005. Mapping potential lake sturgeon habitat in the Lower Bad River complex. Ann Arbor, MI: U.S. Geological Survey, Great Lakes Science Center.

Collins, W., and R. A. McConnaughey. 1998. Acoustic classification of the sea floor to address essential fish habitat and marine protected area requirement. In Proceedings, 1998 Canadian Hydrographic Conference, Victoria, Canada, 361- 368.

Collins, W., R. Gregory, and J . Anderson. 1996. A digital approach to seabed classification. Sea Technology 37:83-87.

Davies, J . 2001. Marine monitoring handbook. Peterborough, UK: Marine SACs Project, J oint Nature Conservation Committee. 183- 197.

GeoAcoustics A Kongsberg Company. 2008. GeoAcoustics. http://www.km.kongsberg.com/ geoacoustics.

Green, R. 2007. Frequency domain electromagnetics. San Antonio, TX: Southwest Research Institute. http://www.swri.org/4org/d20/Geohydro/hydrogeo/elecmag.htm. 
Hamilton, E. L. 1970. Sound velocity and related properties of marine sediments, North Pacific. J ournal of Geophysical Research 75(23):4423- 4446.

Hamilton, E. L. 1972. Compressional-wave attenuation in marine sediments. Geophysics 37:620- 646 .

Kvitek, R., P. Iampietro, E. Sandoval, M. Castleton, C. Bretz, T. Manouki, and A. Green. 1999. Final report early implementation of nearshore ecosystem database project. SIVA Resource Center, Institute for Earth Systems Science and Policy. Seaside, CA: California State University, Monterey Bay.

Lagasse, P. F., B. R. Winkley, and D. B. Simons. 1980. Impact of gravel mining and river system stability. J ournal of Waterway, Port, Coastal, and Ocean Engineering 106(3):00389-404.

Laustrup, M. S., R. B. J acobson, and D. G. Simpson. 2007. Distribution of potential spawning habitat for sturgeon in the Lower Missouri River, 2003-06. USGS Open-File Report 2007-1192. Denver, CO: U.S. Geological Survey Publications Warehouse. http://pubs.usgs.gov/of/2007/1192/.

Lillycrop, W. J., L. E. Parson, and J . L. Irish. 1996. Development and operation of the SHOALS airborne lidar hydrographic survey system. In SPIE selected papers, laser remote sensing of natural waters: from theory to practice, ed. V. I. Feigles and Y. Kopilevich, 2694:26- 37. St. Petersburg, Russia.

Lucius, J . E., W. H. Langer, and K. J . Ellefsen. 2007. An introduction to using surface geophysics to characterize sand and gravel deposits. U.S. Geological Survey Circular 1310. Denver, CO: U.S. Geological Survey Publications Warehouse. http://pubs.usgs.gov/of/2006/1257/.

McGee, R. G., R. F. Ballard, and D. D. Caufield. 1994. A technique to assess the characteristics of bottom and subbottom marine sediments. Technical Report DRP-95-3. Vicksburg, MS: U.S. Army Engineer Waterways Experiment Station.

Murphy, W. L. 1983. Surface and subsurface geologic conditions along selected reaches of the Mississippi River from Rosedale, MS, to Lake Providence, LA. Technical Report GL-83-5. Vicksburg, MS: U.S. Army Engineer Waterways Experiment Station.

Nordin, C. F., and B. S. Queen. 1992. Particle size distribution of bed sediments along the thalweg of the Mississippi River, Cairo, Illinois, to Head of Passes, September 1989. Potamology Program (P-1); Report 7. Vicksburg, MS: U.S. Army Engineer Waterways Experiment Station.

Tamsett, D. 2001. Mapping image texture on side-scan sonar. Norfolk, UK: GeoAcoustics Ltd.

U.S. Fish and Wildlife Service. 1990. Determination of endangered status for the pallid sturgeon: final rule. Federal Register 55:36641- 36647.

U.S. Geological Survey. 2000. Shaded relief bathymetry of Lake Tahoe, CaliforniaNevada.http://walrus.wr.usgs.gov/. 


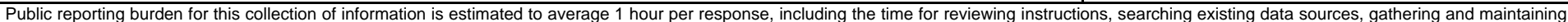

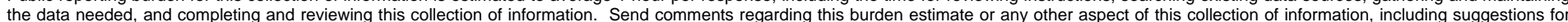

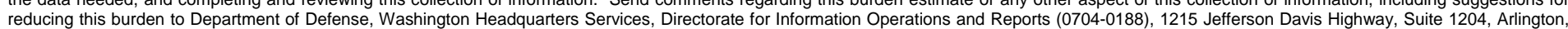

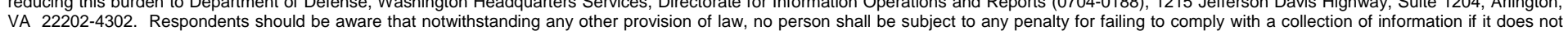
VA 22202-4302. Respondents should be aware that notwithstanding any other provision of law, no person shall be sube
display a currently valid OMB control number. PLEASE DO NOT RETURN YOUR FORM TO THE ABOVE ADDRESS.

\begin{tabular}{l|c}
$\begin{array}{l}\text { 1. REPORT DATE (DD-MM- } Y Y Y Y) \\
\text { July } 2010\end{array}$ & $\begin{array}{c}\text { 2. REPORT TYPE } \\
\text { Final report }\end{array}$ \\
\hline
\end{tabular}

\section{TITLE AND SUBTITLE}

A Literature Review of Processes for Gravel Deposit Identification in the Lower Mississippi River

3. DATES COVERED (From - To)

5a. CONTRACT NUMBER

5b. GRANT NUMBER

5c. PROGRAM ELEMENT NUMBER

\section{AUTHOR(S)}

\section{5d. PROJECT NUMBER}

David S. Biedenharn and Maureen K. Corcoran

5e. TASK NUMBER

5f. WORK UNIT NUMBER

7. PERFORMING ORGANIZATION NAME(S) AND ADDRESS(ES)

8. PERFORMING ORGANIZATION REPORT NUMBER

Biedenharn Group, LLC

3303 Woodlands Place, Vicksburg, MS 39180-5759;

ERDC/GSL SR-10-2

U.S. Army Engineer Research and Development Center

Geotechnical and Structures Laboratory

3909 Halls Ferry Road, Vicksburg, MS 39180-6199

9. SPONSORING I MONITORING AGENCY NAME(S) AND ADDRESS(ES)

U.S. Army Engineer Division, Mississippi Valley

Vicksburg, MS 39181-0080

11. SPONSOR/MONITOR'S REPORT NUMBER(S)

\section{DISTRIBUTION / AVAILABILITY STATEMENT}

Approved for public release; distribution is unlimited.

\section{SUPPLEMENTARY NOTES}

\section{ABSTRACT}

The purpose of this study was to identify feasible techniques for the detection and identification of gravel deposits in the Lower Mississippi River (LMR). This study involved a thorough review of literature concerning investigative techniques used to classify sediment types in bodies of water, as well as interviews with experts in this field. Researchers identified the technique or combination of techniques that have the greatest potential for use on the LMR and recommended a plan for testing those techniques there. This study revealed that direct observation and acoustic techniques can be used to classify the subaqueous bed material in the LMR. Direct observation is obviously the most reliable method, but it is limited to exposed areas of gravel. It is recommended that a detailed visual inspection of the river from Cairo to Old River be conducted with focus on the identification of exposed gravel bars. With respect to acoustical methods, GeoSwath Plus appears to have the greatest potential to map large areas of the river. Both the visual inspections and the GeoSwath Plus system will provide information only about the surface bed material. To assess the potential volume of gravel available in the system, an estimate of the depth of these deposits is needed. Therefore, it is recommended that a subbottom profiling system be applied to the selected test sites to determine its ability to both classify buried gravel strata and determine the vertical extent of these strata. The two-dimensional model being developed by the U.S. Army Engineer Research and Development Center should be applied on the gravel test sites.

\section{SUBJECT TERMS}

GeoSwath

Gravel deposits

16. SECURITY CLASSIFICATION OF:

a. REPORT

UNCLASSIFIED

b. ABSTRACT
UNCLASSIFIED

Lower Mississippi River

Pallid sturgeon

17. LIMITATION

c. THIS PAGE

UNCLASSIFIED OF ABSTRACT

\section{Side-scan sonar}

18. NUMBER OF PAGES

43 19a. NAME OF RESPONSIBLE PERSON

19b. TELEPHONE NUMBER (include area code) 